University of Chicago Law School

Chicago Unbound

Journal Articles

Faculty Scholarship

1996

\title{
Merchant Law in a Merchant Court: Rethinking the Code's Search for Immanent Business Norms
}

Lisa Bernstein

Follow this and additional works at: https://chicagounbound.uchicago.edu/journal_articles

Part of the Law Commons

\section{Recommended Citation}

Lisa Bernstein, "Merchant Law in a Merchant Court: Rethinking the Code's Search for Immanent Business Norms," 144 University of Pennsylvania Law Review 1765 (1996).

This Article is brought to you for free and open access by the Faculty Scholarship at Chicago Unbound. It has been accepted for inclusion in Journal Articles by an authorized administrator of Chicago Unbound. For more information, please contact unbound@law.uchicago.edu. 


\title{
MERCHANT LAW IN A MERCHANT COURT: RETHINKING THE CODE'S SEARCH FOR IMMANENT BUSINESS NORMS
}

\author{
LISA BERNSTEIN†
}

\section{TABLE OF CONTENTS}

INTRODUCTION $\ldots \ldots \ldots \ldots \ldots \ldots \ldots \ldots \ldots \ldots \ldots$

I. MERCHANT LAW AND CoMmERCIAL LAW ........ 1771

A. The NGFA System . . . . . . . . . . . . 1771

1. Usage of Trade . . . . . . . . . . . 1777

2. Course of Performance and Course of Dealing ................... 1781

B. The Code's Adjudicative Approach ... . . . . . 1782

C. Conclusion ... . . . . . . . . . . . . . . . . . . 1782

II. THE THEORY OF LEGALLY UNENFORCEABLE

AGREEMENTS . . . . . . . . . . . . . . . . 1787

III. TRAde USAge, CoURSE of Performance,

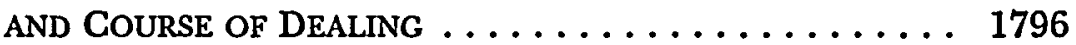

A. Usage of Trade . . . . . . . . . . . . . . 1803

1. Caveat . . . . . . . . . . . . . . 1806

B. Course of Dealing and Course of Performance . . . . . 1807

1. Flexibility ................. 1808

2. Renegotiation $\ldots \ldots \ldots \ldots \ldots \ldots \ldots \ldots \ldots \ldots 1811$

3. Cooperation $\ldots \ldots \ldots \ldots \ldots \ldots \ldots \ldots \ldots . \ldots 1812$

† Professor of Law, Georgetown University Law Center. Special thanks are due to David Barrett and the members of the National Grain and Feed Association who talked to me about both the Association and the industry. Thanks are also due to Avery Katz, Steven Shavell, Louis Kaplow, Amy Howe, Marcel Kahan, Tamar Frankel, Stewart Macaulay, Richard Pildes, Eric Posner, Edward Bernstein, Richard Epstein, Bill Vukovich, Warren Schwartz, Jason Johnston, Paul Dubinsky, Mitchell Berman, Curtis Reitz, Deborah Healy, Maureen O'Rourke, Andrea Adelman, Richard Speidel, Gary Zeiss, William Mulherin, David Charny, David Dana, Daniel Klerman, and participants at the Georgetown University Law and Economics Workshop, the New York University Faculty Workshop, the Stanford Law and Economics Workshop, the University of California at Berkeley Law and Economics Workshop, the Harvard Law and Economics Workshop, the Yale Law, Economics \& Organization Workshop, the Harvard Faculty Workshop, the Northwestern University Faculty Workshop, the American Bar Foundation Workshop, the 1996 American Law and Economics Association Annual Meeting's Panel on Contracts, and the University of Pennsylvania Law Review Symposium on Law, Economics, \& Norms. This research is part of a larger project on private commercial law supported by a grant from the National Science Foundation, SBR-9422795. 
4. Caveat .................. 1813

5. Other Distortions ................ 1813

C. Expansion of Commercial Practices ............ 1814

IV. THE IMPORTANCE OF TRANSACTIONAL AND

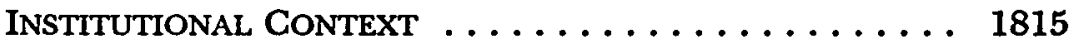

A. Transactional Context $\ldots \ldots \ldots \ldots \ldots \ldots \ldots \ldots 1816$

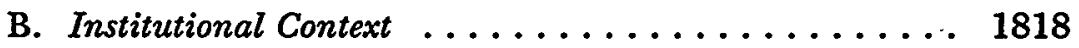

Conclusion . . . . . . . . . . . . . . . . . . . 1820

\section{INTRODUCTION}

This Article draws on a case study of merchant law in a merchant court to reexamine, and, ultimately, to challenge, the fundamental premise of the Uniform Commercial Code's adjudicative philosophy, the idea that courts should seek to discover "immanent business norms" and use them to decide cases." This philosophy finds expression in specific Code sections ${ }^{2}$ and Official Comments, ${ }^{3}$ judicial opinions, ${ }^{4}$ academic commentary, ${ }^{5}$ and the

' Although for simplicity of exposition this Article refers to the Uniform Commercial Code ("the Code"), its focus is exclusively on Article 2 as supplemented by the pertinent general and definitional sections of Article 1.

${ }^{2}$ See, e.g., U.C.C. \$ 1-102(2)(b) (1991) ("Underlying purposes and policies of this Act are ... to permit the continued expansion of commercial practices through custom, usage and agreement of the parties . . . ."); id. \$ 1-103 ("Unless displaced by the particular provisions of this Act, the principles of law and equity, including the law merchant ... shall supplement its provisions."); $i d$. \$ 2-314(2)(a) ("Goods to be merchantable must . . . pass without objection in the trade under the contract description ...."); id. § 2-314(3) ("[I]mplied warranties may arise from course of dealing or usage of trade."); id. $\$ 2-504(\mathrm{~b})$ (requiring a seller to provide those shipping documents required by usage of trade); id. \$2-609(2) ("Between merchants the reasonableness of grounds for insecurity and the adequacy of any assurance offered shall be determined according to commercial standards.").

${ }^{3}$ See, e.g., id. \$ 1-102 cmt. 1 ("This Act is drawn . . . [to] provide its own machinery for expansion of commercial practices."); id. $\$ 1-205 \mathrm{cmt}$. 1 ("[T] he meaning of the agreement of the parties is to be determined by the language used by them and by their action, read and interpreted in the light of commercial practices and other surrounding circumstances. The measure and background for interpretation are set by the commercial context, which may explain and supplement even the language of a formal or final writing."); id. $\$ 2-202 \mathrm{cmt}$. 1(b) (explaining that language is to be given the "meaning which arises out of the commercial context in which it was used"); id. $\S 2-202 \mathrm{cmt}$. 2 ("[W]ritings are to be read on the assumption that the course of prior dealings between the parties and the usages of trade were taken for granted when the document was phrased."); id. $\$ 2-603 \mathrm{cmt}$. 1 (recognizing "the duty imposed upon the merchant buyer by good faith and commercial practice to follow any reasonable instructions of the seller as to reshipping, storing, delivery to a third party, reselling, or the like"). 
Documents that are arguably part of the Code's legislative history also discuss this idea. See, e.g., Walter D. Malcolm, The Proposed Commercial Code, 6 Bus. LAW. 113, 126 (1951) (" $[T]$ he practices of businessmen and business houses are important factors in construing their contracts and actions and in determining their rights and liabilities .... [M] [any of the changes effected by the Code are designed to adapt rules of law to the way that business is actually carried on." (quoting the Report of the Committee on the Proposed Commercial Code)).

4 See infra cases cited notes $66,68,74$.

5 See, e.g., ALAN SchwaRTZ \& ROBERT E. ScotT, Commercial TRANSActions: PRINCIPLES AND POLICIES 8-9 (2d ed. 1991) ("Article II of the Code can profitably be viewed as adapting the philosophy of 'immanent law' to a specific context. . . . [It] frequently speaks as though courts should discover the law merchant from a careful, disinterested examination of custom and fact situations."); Richard Danzig, A Comment on the Jurisprudence of the Uniform Commercial Code, 27 STAN. L. REV. 621, 624, 635 (1975) (suggesting that to Llewellyn, "an 'immanent law' lay embedded in any situation and the task of the law authority was to discover it .... [T] he animating theory of Article II is that the law is immanent. The law job is to search it out .... [It] is a document whose thrust is . . . to coerce courts into looking for law in life."); James Whitman, Note, Commercial Law and the American Volk: A Note on Llewellyn's Germanic Sources for the Uniform Commercial Code, 97 YALE L.J. 156, 159-66 (1987) (discussing the Germanic origin of Llewellyn's dedication to the search for "immanent business norms"). In addition, many scholars have suggested that the Code does not give enough weight to "immanent business norms." See, e.g., Jay M. Feinman, The Significance of Contract Theory, 58 U. CIN. L. REv. 1283, 1304 (1990) ("Relational contract theory suggests that solving the problem [of contract interpretation] begins with the definition of norms which are immanent in the context."); Ian R. Macneil, Contracts: Adjustments of Long-Term Economic Relations Under Classical Neoclassical, and Relational Contract Law, 72 Nw. U. L. REV. 854, 898 (1978) (suggesting that the neoclassical approach to contract law be replaced by relational contract law in which "recognition is easily accorded to the creation of such [contractual] interests arising naturally from any behavior patterns within the relation"); Richard E. Speidel, Article 2 and Relational Sales Contracts, 26 LoY. L.A. L. REV. 789, 804-05 (1993) (suggesting that the Code's definition of agreement "should be revised to clearly incorporate into the contract internal norms generated by the relationship"); Russell J. Weintraub, $A$ Survey of Contract Practice and Policy, 1992 WIS. L. REV. 1, 21 ("An important lesson that can be learned from relational contracts is the methods of accommodation parties of approximately equal bargaining power use when disputes arise. These methods should be reflected in legal rules to reinforce decent practice."). One scholar has argued that relational norms should be given additional weight in the franchise context. See Gillian K. Hadfield, Problematic Relations: Franchising and the Law of Incomplete Contracts, 42 STAN. L. ReV. 927, 991-92 (1990) ("The necessary incompleteness of the franchise contract prompts an examination of the norms and practices-the relational structure of franchising-to identify the complete content of the franchisor and franchisee's exchange."). Other scholars have suggested that these norms should be used to develop commercial law in formerly socialist countries, or to improve commercial law in common law countries. See Robert D. Cooter, Structural Adjudication and the New Law Merchant: A Model of Decentralized Law, 14 INT'L REV. L. \& ECON. 215, 226 (1994) ("The role of the state in a decentralized legal system is to elevate appropriate social norms to the level of law[,] . . . lawmakers should identify the actual norms that have arisen in business communities[,] ... . identify the incentive structures that produced the norms[,] . . . [and enforce $t]$ hose business norms that arise from an efficient incentive structure."); Paul H. Rubin, 
writings of the Code's principal drafter, Karl Llewellyn. ${ }^{6}$ Most importantly, it is the basis of the Code's definition of agreement, which includes "the bargain of the parties in fact as found in their language or by implication from other circumstances including course of dealing or usage of trade or course of performance. ${ }^{n 7}$ The Article 2 Editorial Board recently reaffirmed that "reducing the gap between law and practice ... in the relevant business community" ${ }^{\prime 8}$ remains a primary objective of the Code. It is currently considering amendments that would broaden the reach of the Code's course of dealing, course of performance, and usage of trade provisions. ${ }^{9}$

This Article challenges the idea that courts should seek to discover and apply immanent business norms in deciding cases. ${ }^{10}$

Growing a Legal System in the Post-Communist Economies, 27 CORNELLL INT'L L.J. 1 (1994) (suggesting that trade associations should be formed to interpret and enforce contracts according to commercial custom so that, over time, customs will become sufficiently well developed to supply the basic principles of a public commercial law); see also Robert D. Cooter, Decentralized Law for a Complex Economy: The Structural Approach to Adjudicating the New Law Merchant, 144 U. PA. L. REv. 1643, 1646 (1996) (suggesting that as an economy increases in complexity, it becomes increasingly important for courts to enforce certain types of business custom).

${ }^{6}$ See, e.g., Karl N. Llewellyn, The First Struggle to Unhorse Sales, 52 HARV. L. REV. 873, 903-04 (1939) (containing a "plea for merchants' law to be recognized and be further made for merchants"); Karl N. Llewellyn, On Warranty of Quality, and Society: II, 37 ColuM. L. REv. 341, 389 n.124 (1937) (criticizing the Uniform Sales Act for "the amazing degree to which it has failed to reflect either commercial understanding or commercial need"); see also NATIONAL CONFERENCE OF COMM'RS ON UNIFORM STATE LAWS, REPORT AND SECOND DRAFT: THE REVISED UNIFORM SALES ACT 253-54 (1941) (noting, in a comment thought to have been drafted by Llewellyn, that while "the law about the effect of 'business custom' is quite . . . uncertain . . . that has not been because any sane Court for half-a-century doubted the wisdom of fully incorporating the relevant usage of trade into the agreement and into the adequacy of performance").

${ }^{7}$ U.C.C. \$ 1-201(3).

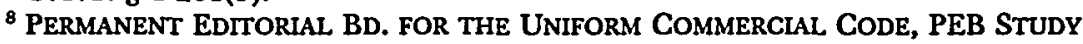
Group UNIForM COMMERCIAL CODE ARTICle 2: PRELIMINARY REPORT 9 (1990).

9 The preliminary report of the Article 2 Study Group emphasized that the Code's provision on course of dealing and usage of trade, UCC $\S 1-205$, "is a crucial component of the [Code's] broad definition of agreement." Id. at 32 . It also recommended moving UCC $\$ 2-208$, course of performance or practical construction, to Article 1, because "[t]his important principle of interpretation should not be limited to contracts for the sale of goods." Id.

${ }^{30}$ The desirability of commercial law attempting to mirror actual business practices has, with some notable exceptions, gone largely unchallenged. See David Charny, Hypothetical Bargains: The Normative Structure of Contract Interpretation, 89 MICH. L. REV. 1815, 1850-63 \& n.149 (1991) [hereinafter Charny, Hypothetical Bargains] (suggesting that courts should "try to distinguish between customs that are efficient to use as nonlegal customs, i.e., standard social practices, as contrasted to 
It demonstrates that while the drafters of the Code sought to incorporate these norms into the law in an effort to make commercial law more responsive to and reflective of commercial reality, they failed to recognize that this approach would fundamentally alter the very reality they sought to reflect, and would do so in ways that would have undesirable effects on commercial relationships and would undermine the Code's own stated goals of promoting flexibility in commercial transactions and "permit[ting] the continued expansion of commercial practices through custom, usage and agreement of the parties." 11

In the spirit of the Code and Karl Llewellyn, this Article begins by looking at merchant practice. It presents a case study of the private legal system created by the National Grain and Feed Association ("NGFA") to resolve contract disputes among its members. The study pays especially close attention to the willingness of NGFA's industry-expert adjudicators to take trade usage, ${ }^{12}$ course of dealing, and course of performance into account in deciding cases. It finds that despite their industry expertise, NGFA arbitrators are reluctant to look to these indicia of immanent business norms. Unlike courts, which often permit course of dealing, course of performance, and usage of trade to trump express written terms, NGFA arbitrators take a formalistic approach

customs that should be enforced as well as a legal or contractual matter"); David Charny, Nonlegal Sanctions in Commercial Relationships, 104 HARV. L. REV. 373 (1990) [hereinafter Charny, Nonlegal Sanctions] (arguing that nonlegal commitments should only be enforced in certain narrowly defined situations); Jason S. Johnston, The Statute of Frauds and Business Norms: A Testable Game-Theoretic Model, 144 U. PA. L. REv. 1859, 1862 (1996) (questioning whether it is "really appropriate to apply norms that evolve in the context of ongoing relationships-relationships governed primarily by extralegal sanctions-to the resolution of litigated disputes that the parties, by definition, did not anticipate," but concluding that in some situations it may be); see also Eric A. Posner, The Regulation of Groups: The Influence of Legal and Nonlegal Sanctions on Collective Action, 63 U. CHI. L. REV. 133, 136 (1996) (discussing the effects of "legal rules designed to regulate intragroup relations," and concluding that "with the exception of rules that deter extreme bad faith conduct, even rules that merely duplicate the group's own norms will generally undermine self-regulation"). For a challenge to the idea that courts should enforce customary norms as implied contractual obligations in the employment setting, see Edward B. Rock \& Michael L. Wachter, Internal Labor Markets, Norms, and Law, 144 U. PA. L. REv. 1913, 1932-38 (1996).

11 U.C.C. $\$ 1-102(2)(b)$.

12 This Article uses the terms "custom" and "trade usage" interchangeably even though it is far easier to establish a trade usage under the Code than it was to establish a custom at common law. See id. $\$ 1-205 \mathrm{cmt}$. 4 (distinguishing the Code's meaning of usage from the common law meaning of custom). 
to adjudication. They do not permit these considerations to vary either trade rules or written contractual provisions. This Article develops a theory to explain why sophisticated merchant-transactors might find NGFA's approach to adjudication preferable to the Code's approach, and then draws on it to analyze the effects of the Code's adjudicative approach on commercial relationships.

Part I describes NGFA's private legal system and compares its tribunal's adjudicative philosophy to the adjudicative philosophy underlying the Code. Part II discusses the reasons that sophisticated transactors might allocate some aspects of their contracting relationship to the legal realm and some to the extralegal realm, or might include a provision in their written contract while acting or agreeing to act in another, perhaps contradictory, way. It suggests that recognizing the reasons that rational transactors may act or agree to act in ways that may contradict the terms of their contract undermines an important assumption underlying the Code's definition of agreement, namely that "the course of actual performance by the parties is ... the best indication of what they intended the[ir] writing to mean. ${ }^{n 13}$ It then reconsiders the desirability of the Code's definition of agreement under the more realistic assumption that there is no necessary connection between transactors' actions and their intended meaning of the written provisions in their contract. It concludes that because the Code makes it difficult to enter into purely extralegal self-enforcing agreements, it prevents transactors from selecting the valuemaximizing combination of legal and extralegal terms.

Part III is the core of the analysis. It begins by suggesting that transactors do not necessarily want the relationship-preserving norms ${ }^{14}$ they follow in performing contracts and cooperatively resolving disputes among themselves to be used by third-party neutrals to decide cases when they are in an end-game situation. ${ }^{15}$ After presenting evidence that merchants implicitly recognize the distinction between relationship-preserving and end-game norms, it suggests that when courts apply the Code's usage of trade, course of dealing, and course of performance provisions, they will often be using relationship-preserving norms to resolve end-game disputes.

${ }^{13} I d . \S 2-202 \mathrm{cmt} .2$.

${ }^{14}$ See infra note 101 and accompanying text (defining relationship-preserving norms).

${ }^{15}$ See infra notes 102-04 and accompanying text (discussing the meaning of endgame). 
It then explores the effects of this aspect of the Code's adjudicative approach on contracting relationships, and demonstrates that this approach both prevents transactors from selecting their preferred mix of legal and extralegal terms and makes them less willing to flexibly adjust their contracting relationships. It also suggests that this approach may undermine transactors' attempts to create the contracting framework that will best promote successful renegotiation and long-term cooperation. Part III concludes by exploring the reasons that the Code's adjudicative approach may inhibit the "expansion of commercial practices." 16

Part IV returns to the case study and considers the reasons that NGFA's adjudicative approach is particularly well-suited to the private adjudication of grain and feed disputes. Finally, the Article concludes by offering some preliminary thoughts on the implications of the empirical observations and analysis presented in earlier sections for reform of the Code.

\section{MERCHANT LAW AND COMMERCIAL LAW}

The merchant-court system developed by the NGFA provides an unusual opportunity to empirically explore and reevaluate the Code's search for immanent business norms in a context where the concerns of litigation costs and institutional competence that have been the focus of the limited debate about the Code's adjudicative approach are conspicuously absent. This Part describes the operation of the NGFA system and compares the extent to which NGFA arbitrators applying the Association's trade rules and courts applying the Code are willing to look to usage of trade, course of dealing, and course of performance in deciding cases. It demonstrates that despite the industry-specific expertise and business acumen of NGFA arbitrators, in practice they give far less weight to these indicia of immanent business norms than do generalist courts applying the Code.

\section{A. The NGFA System}

The NGFA is a trade association of firms and individuals who are active in the cash-markets for grain and feed. It began arbitrating disputes in 1896 and has been publishing written arbitration opinions since 1902. As a condition of membership in the Associa-

${ }^{16}$ U.C.C. § 1-102(2)(b). 
tion, members must agree to submit all disputes with other members to the Association's arbitration system. ${ }^{17}$ A member who refuses to submit to arbitration or fails to comply with an arbitration award rendered against him may, in addition to having his actions reported in the NGFA newsletter, be suspended or expelled from the Association. ${ }^{18}$

The NGFA has adopted four sets of substantive trade rules that are designed to "reflect trade practice and facilitate trade between NGFA members."19 The Grain Rules and the Feed Rules each cover the basics of contract formation, performance, repudiation, breach, damages, and excuse. The Barge Rules supplement these rules whenever "shipments are designated by contract to be

${ }^{17}$ See NGFA BYLAwS, art. II, § 2(f). The NGFA Trade Rules and Arbitration Rules are published in booklet form each year and are reprinted, along with the Bylaws, in the Annual NGFA Directory/Yearbook. See, e.g., NGFA, NGFA DIRECTORY/ YEARBOOK 1994-95, at 330-50, 359-62, 368-75 (1995) [hereinafter NGFA DIRECTORY]. The NGFA arbitration opinions can be found in NGFA, PROTECTING YOUR COMPANY'S INTEREST IN TRADING AGRICULTURAL COMMODITIES (1991 \& Supp.) [hereinafter NGFA, PROTECTING].

${ }^{18}$ See NGFA BYLAWS, art. IX, § 2(a)-(c) (explaining some of the grounds for expulsion or suspension); id. art. $\mathrm{X}, \S 1$ (describing the procedure for expelling a member). Between 1975 and 1995, three members were expelled for refusing to arbitrate. See American Commercial Barge Line Co., NGFA Misc. Case No. 2 (1995) (expelling ACBL and noting that "it is the NGFA's long-standing interpretation of the NGFA Bylaws, Trade Rules and Arbitration Rules that compulsory arbitration of disputes is not a matter that can be altered by a member's contractual documents and is a fundamental obligation of membership"); Houston Pub. Elevator, NGFA Misc. Case No. 1 (1988) (expelling Houston Public Elevator, explaining that " $[w]$ ithout compulsory arbitration, the process would be used only when convenient in defending a given position" and noting that the "equality that all members, large and small, now enjoy in seeking fair play would quickly evaporate"); S.M. Whitney Co. v. Mundy, Inc., NGFA Case No. 1626 (1985) (expelling Mundy, Inc.). During this period, one member was expelled for failure to comply with an arbitration award.

${ }^{19}$ NGFA GRAIN TRADE R. pmbl. When the trade rules were originally adopted, custom was the starting point for the codifiers. However, changes in unwritten customary practices have not been the primary motivation for trade rule amendments. Rather, amendments have been primarily: (1) technical wording changes designed to correct typographical errors or enhance clarity; (2) changes motivated by arbitration opinions suggesting that a rule was unclear, unworkable, or undesirable; (3) changes introduced in response to technological innovations; (4) changes introduced in response to changes in state or federal regulations; and, finally, (5) changes introduced in response to important changes in the market. In addition, at least one change was explicitly designed to change an existing custom. See NGFA, WHO'S WHO IN THE GRAIN TRADE 37 (Nov. 1920) (reporting that the newly adopted Rule 29 provides that "the specifications of a contract cannot be altered or amended without express consent of both the buyer and the seller (this abolishes the custom of silence confirms)"). 
transported by barge, ${ }^{n 20}$ and the Barge Freight Trading Rules "govern all disputes [involving] ... the purchase and/or sale of barge transportation." ${ }^{21}$ Unless they have been explicitly altered or excluded by a specific contractual provision, these rules govern all contracts between NGFA members. Together, they provide a comprehensive set of default rules governing the most important aspects of cash-market transactions in grain or feed.

The trade rules are supplemented by a highly detailed set of arbitration rules, whose applicability to disputes between NGFA members cannot be altered by contract. These rules set out the required filing fee, ${ }^{22}$ the guidelines for the selection of arbitrators, ${ }^{23}$ the types of information each party must provide to the tribunal, ${ }^{24}$ the procedures for requesting an oral hearing, ${ }^{25}$ the type of information the arbitrators should include in their written opinions, ${ }^{26}$ and the procedures for filing and conducting an intra-

${ }^{20}$ NGFA BARGE TRADE R. pmbl.

21 NGFA BARGE FREIGHT TRADING R. pmbl.

${ }^{22}$ See NGFA ARB. R. 5(c) (noting that the required fee ranges from $\$ 200$ to $\$ 1500$ depending on the amount at stake).

${ }^{23}$ The primary arbitration committee is composed of three members chosen by the National Secretary "with a view to forming each committee of prominent people experienced in the type of trade involved in the cases to be brought before it." NGFA ARB. R. 4(a). Arbitrators are required to disclose any circumstance that could affect their impartiality, see NGFA ARB. R. 8(a), and may recuse themselves from particular cases. Parties may also challenge the selection of an arbitrator "for prejudicial or other causes." NGFA ARB. R. 8. The National Secretary then determines whether the arbitrator should be replaced. See id.

${ }^{24}$ See NGFA ARB. R. 6(a) ("[P]art[ies] will be expected to furnish . . . [the arbitrators with the] contract or contracts, if any, including all written evidence, letters, and telegrams, tending to establish the terms and conditions[,] . . [t] he confirmation of the contract ....; Shipping directions, if any; Bills of lading, if any; Inspection certificates from point of shipment, if any; Inspection certificates from point of destination, if any; Freight expense bills, if there is any dispute regarding freight paid; Confirmation of freight rates, when that question enters into the case; Authority for freight rate, when difference of rate is involved; Proof of market difference ... [which] might be the price bulletin of the market to which the grain in question was shipped, or intended to be shipped, . . . but in case it is necessary to establish such difference in a market where no price bulletin is regularly issued, affidavits by disinterested parties should be furnished.").

${ }^{25}$ An oral hearing must be held if the chairman of the arbitration panel or either party requests it. See NGFA ARB. R. 8(b)(3), (f). Otherwise, the chairman decides whether to "call[] a meeting of the members of a Committee," to reach a decision "b]y passing the papers from one [committee member] to another by mail," or to use "such other means as the Chairman may deem necessary." NGFA ARB. R. 8(b). A party who requests a hearing is required to post a bond for hearing costs, but most cases are decided without an oral hearing.

${ }^{26}$ See NGFA ARB. R. 8(m) (providing that opinions must specify: "(1) [t]he names of the plaintiff and the defendant; (2) [t]he award(s) of the Committee, giving the 
association appeal. ${ }^{27}$ They include a one-year statute of limitations. ${ }^{28}$ Under the trade rules, the time from filing to judgment is supposed to be less than six months. ${ }^{29}$

The typical cash-market transaction in grain or feed that is governed by these rules is negotiated on the telephone, sometimes with the assistance of a broker, and is promptly confirmed through the exchange of written, largely standard-form, confirmatory memoranda. ${ }^{30}$ The most common issues arbitrated are those that NGFA classifies as dealing with confirmations, custom of the trade, grades, failure to deliver, and weight. ${ }^{31}$ Arbitrated disputes over unforeseen contingencies are rare. Claims of commercial impracticability are infrequently raised and almost never successful. ${ }^{32}$

names of the plaintiff and defendant in each case, the nature of the case and the amount involved, the award and such other information as may be of interest to the members; (3) [n] otice of failures to comply with the terms of awards, giving a record of each case; (4) [n]otice of refusals to arbitrate . . ; (5) [n]otice of failures to answer the correspondence of the National Secretary relative to arbitration").

${ }^{27}$ See NGFA ARB. R. 9 (providing guidelines for selecting the five-member appeals panel, requiring the losing party to post a bond in the amount of the judgment, specifying the appeals fee, and giving the parties the right to request an oral hearing).

${ }^{28}$ See NGFA ARB. R. 3(d). The Code's statute of limitations is four years. See U.C.C. $\S 2-725(1)$.

${ }^{29}$ See NGFA ARB. R. 7(b)-(h), 8(k) (setting out the timing requirements for the filing of cases and the making of an award). However, many cases take longer, particularly when there are multiple parties or a natural disaster leads to the simultaneous filing of numerous cases. See Panel Discussant, Remarks at the National Grain and Feed Association Centennial Convention (Mar. 1996).

${ }^{30}$ The trade rules provide that these memoranda should include certain basic information about the trade. See NGFA GRAIN TRADE R. 1 ("It shall be the duty of both the Buyer and the Seller, to include in their original articles of trade . . . the following specifications ... : (a) Date of Contract[;] (b) Quantity[;] (c) Kind and Grade of Grain[;] (d) Price[;] (e) Type of inspection[;] (f) Type of weights[;] (g) Applicable Trade Rules to apply[;] (h) Transportation specifications .. . [i] (i) Payment Terms[; and] (j) Other terms."). There is also a rule dealing with the "battle of the forms," the situation where each transactor sends a confirmatory memorandum but the terms of the memoranda fail to agree. See NGFA GRAIN TRADE R. 6.

${ }^{31}$ According to the NGFA case index, from 1975 to 1993,42 cases dealt with confirmations (primarily "battle of the forms" issues), 38 with custom of the trade, 37 with grades (quality difference), 30 with grades (method of inspection), 26 with failure to deliver, and 19 with weight (type of weight to be employed).

32 See, e.g., Owensboro Grain Co. v. David G. Cline, NGFA Case No. 1620 (1985) ("Failure to produce a crop [because of a drought] does not void a contract for grain delivery, since that grain is available somewhere. It may be difficult to complete the delivery. It will probably be costly to complete the delivery. But it is not impossible."); Monarch Feed Mills Inc. v. David McEntire, NGFA Case No. 1596 (1983) (same). Interestingly, a desire to avoid the Code's provisions on commercial impracticability, see U.C.C. $\$ 2-615$, is one reason that grain traders prefer to contract under the NGFA system. See NGFA, Protecting, supra note 17, at 143 (listing the benefits of arbitration over litigation, including the fact that " $[t]$ he language . . . [of the UCC's 
In deciding cases, the NGFA arbitrators take a formalistic approach to adjudication; they consistently refuse to look behind the letter of a trade rule to discern and take into account the type of behavior that the rule is intended to encourage or discourage. ${ }^{33}$ The trade rules do not contain an explicit equivalent of the Code's broad duty of good faith. ${ }^{34}$ Although the term "good faith" occasionally appears in NGFA opinions ${ }^{35}$ and is sometimes used to

impracticability provision] actually confuses, rather than clarifies, the predictability of the outcome in the court system. It is actually better in arbitration than in court.").

Even when contracts include enforceable force majeure provisions, the industrywide norm in the event of a force majeure is to extend the time for contractual performance or voluntarily tender damages for breach, rather than to claim excuse. As one grain company executive explained, there is a sense that, as between merchandisers who are both buyers and sellers in the market, a norm of never declaring force majeure will work out fairly over time. He recounted one situation where a seller declared force majeure on a number of contracts, due to a deep freeze on several key inland waterways. The executive pointed out to the seller that if he persisted in declaring force majeure in the instant situation, the executive's company would be particularly quick to call force majeure on the seller's company in the first instance where the transactors' positions were reversed. The seller immediately withdrew his claim of force majeure and tendered the requisite compensatory payment. See Interview with Grain Company Executive (Nov. 1995). As another trader explained, in more colloquial terms, "Act of God? Whose God? I'm Catholic, he's a Methodist." See Comment of a Panelist at the NGFA Agricultural Transportation Summit 1996 (May 1996).

ss In Pillsbury Co. v. Cook Industries, NGFA Case No. 1530 (1977), for example, the contract provided that official destination weights were to govern. At issue was the validity of a destination weight determined by a clamshell unloader scale. The plaintiff argued that the weight should be considered invalid, because NGFA Barge Trade Rule 2 provided that "[g]rain loaded or unloaded[] by clamshell . . . shall not be considered officially weighed." The defendant maintained that this rule applied "only to older, inefficient versions" of the clamshell. Id. He argued that because the weight of this particular scale was generally accepted by shippers, allowing its weights to be accepted as official weights would be consistent with the rule's intent. The arbitrators recognized that this scale's weights were commonly accepted in lieu of official weights and that "this particular clamshell ... appeared efficient with advanced engineering to provide accurate weights." Id. Nevertheless they held for the plaintiff, explaining that "[i]f trade practices are changing, consideration should be given to updat[ing] the rules to reflect such changes." Id. This aspect of the opinion was upheld on appeal. See Cook Indus. v. Pillsbury Co., NGFA Arb. App. Case No. 1530 (1977). The trade rule was ultimately amended.

${ }^{34}$ See U.C.C. \$ 1-203 ("Every Contract . . . imposes an obligation of good faith in its performance .... ). The only reference to good faith in the NGFA Trade Rules is in a technical provision dealing with the role of brokers. See NGFA GraIN TRADE R. 40.

${ }^{95}$ For example, "good faith" is sometimes mentioned in cases where one or both parties alleged intentional wrongdoing by the other party. See, e.g., U. \& L. Grain Co. v. Continental Grain Co., NGFA Case No. 1528 (1976) (where the plaintiff alleged that "possible substitution of corn in the one compartment [of a train car] by the 
signal the arbitrators' view of the propriety of a party's commercial behavior, or to provide additional support for a result reached on other grounds, ${ }^{36}$ violation of a general duty of good faith is never the explicit basis of the arbitrators' decision. ${ }^{37}$ In a recent case, NGFA held that acting in accordance with the trade rules and the terms of the written contract is per se acting in "good faith. ${ }^{\text {38 }}$

NGFA arbitrators follow a strict hierarchy of authority, derived

receiver" might explain its "heating and sour" condition, the arbitrators found the allegation of intentional wrongdoing unsupported and noted that, in handling the settlement of the shipment, the defendant acted in "good faith"). Occasionally, the arbitrators note that a party made an argument based on "good faith" but do not mention it in stating the basis of their decision. See, e.g., Dillwyn Grain and Supply Co. v. Farmers Commodities Corp., NGFA Case No. 1639 (1987) (noting that the defendant maintained that it acted in "good faith," the arbitrators found in its favor on other grounds).

${ }^{36}$ See, e.g., Pillsbury Co. v. Louis Dreyfus Corp., NGFA Case Nos. 1568, 1570 (1982) ("question[ing] the validity of [a company's] statement of taking positive action in good faith on the [date claimed]" because this date "would [have been] the very last day ... to make shipment" under the Grain Trade Rules and the terms of the contract); R.F. Cunningham \& Co. v. Pennfield Corp., NGFA Case No. 1544 (1978) (holding that a defendant who claimed that the plaintiff had submitted an inaccurate weight certificate had no recourse because the plaintiff provided the type of certificate required by the contract, and noting that the defendant "failed in good faith to immediately notify the Plaintiff of such claimed shortage").

${ }^{37}$ Notions of good faith and substantive fairness may, however, influence the outcome of arbitration cases in ways that cannot be detected by reading opinions. These considerations may subtly influence the arbitrators' factual findings in outcome-determinative ways, particularly in situations where the case turns on the credibility of conflicting oral testimony. Arbitrators' occasional references to good faith as an additional justification for conclusions reached on alternative grounds suggest that good faith is very much on their minds when they decide cases. Preliminary interviews with arbitrators have so far failed to establish that good faith influences outcomes. However, this may reflect nothing more than arbitrators' reluctance to acknowledge that their decisions have been influenced by impermissible factors. Because NGFA hearing transcripts and written filings are not available to the public, it is impossible to determine definitively the extent to which good faith influences arbitrators' decisions. It is clear, however, that NGFA arbitrators are reluctant to appear to be ruling on the basis of good faith alone.

${ }^{38}$ See, e.g., Farmland Indus. v. Bartlett \& Co., NGFA Case Nos. 1739, 1739B (1996) (holding that because the defendant acted in accordance with both the contract's written provisions and the trade rules, there was no issue of good faith under the Code to consider, because "before going to an outside source, a dispute first must be examined within the four corners of the document from which the dispute arises"); see also Farmland Indus. v. Benson-Quinn Co., NGFA Case Nos. 1737, 1737B (1996) (rejecting a claim that defendants who had complied with all applicable contract and trade rule provisions should nonetheless be found to have breached the Code's duty of good faith and fair dealing); Farmland Indus. v. Bartlett \& Co., NGFA Case Nos. 1732, 1732B (1996) (same). 
from both the trade rules ${ }^{39}$ and prior arbitration decisions. ${ }^{40}$ As one opinion explained, the arbitrators'

first responsibility was to enforce the terms of the contract. When the contract terms are insufficient on their own to decide the case, arbitrators are to rely next upon the Trade Rules, and thirdly, trade practice. Reliance upon the Uniform Commercial Code or any other statutory basis usually comes only after the first three sources have proved insufficient."

In practice NGFA arbitrators rarely look to the Code or other legal sources in deciding cases.

\section{Usage of Trade}

A review of all the NGFA opinions in which custom or usage of trade was at issue between 1975 and $1995^{42}$ suggests that NGFA arbitrators adhere strictly to the Association's stated hierarchy of authority. The NGFA tribunal does not permit unwritten customs and usages of trade to vary or qualify the meaning of either trade rules or explicit contractual provisions. Arbitrators use custom to decide cases only when both the trade rules and the contract are silent. ${ }^{43}$ Yet even when looking to custom to fill a true contractual

${ }^{39}$ See NGFA GRAIN TRADE R. pmbl. ("All active members are free to agree upon any contractual provisions which they deem appropriate and these rules apply only to the extent that the parties to a contract have not altered the terms of the rules, or the contract is silent as to a matter dealt with by the pertinent rule."); see also NGFA BARGE FREIGHT TRADING R. pmbl. (same); NGFA BARGE TRADE R. pmbl. (same); NGFA FEED TRADE R. pmbl. (same).

to NGFA opinions do not have precedential value. However, arbitrators occasionally refer to earlier opinions. See, e.g., ConAgra Inc. v. Peavey Co., NGFA Case No. 1559 (1981) (discussing the relevance of NGFA Case No. 1515's definition of the boundaries of C.I.F. NOLA).

${ }^{11}$ Louis Dreyfus Corp. v. Peavey Co., NGFA Case No. 1690 (1992); see also William Prahl v. Didion Inc., NGFA Case No. 1702 (1993) (same); Pillsbury Co. v. Louis Dreyfus Corp., NGFA Case Nos. 1568, 1570 (1982) (same).

12 The discussion in the text is based on the opinions in 39 cases, decided between 1975 and 1995, that NGFA classified as involving issues relating to "custom of the trade," as well as on the opinions in $\mathbf{1 2}$ additional cases that the Author, after reviewing all of the opinions, classified as dealing, either explicitly or implicitly, with custom or usage of trade. The NGFA arbitration opinions rendered between 1975 and 1995 can be found in NGFA, Protecting, supra note 17. The discussion also draws on interviews with current and former NGFA arbitrators.

${ }^{13}$ See, e.g., Coshoction Grain Co. v. Tim Geiger, NGFA Case No. 1752 (1996) (acknowledging that both the contract and the trade rules were silent on the relevant issue, the arbitrators ruled for the plaintiff on the ground that its actions were "consistent with customary trade practice"); Montana Merchandising Inc. v. PennyNewman Grain Co., NGFA Case No. 1614 (1985) (applying "the custom of the trade 
gap, the arbitrators often signal their distaste for this type of adjudication by admonishing the parties that the dispute might well have been avoided had they written a sufficiently specific contract. When custom conflicts with a trade rule or an explicit contractual provision, the arbitrators decide the case on the basis of the trade rule $^{44}$ or the contractual provision ${ }^{45}$ even when they are convinced that the custom both exists and was known by the parties. ${ }^{46}$

that billed weights are utilized" in a situation where the defendant failed to weigh several cars in accordance with the terms of the contract and supplied weights that the trade rules state are inapplicable in such a situation); Feeders Grain Co. v. Italgrani U.S.A. Inc., NGFA Case No. 1575 (1982) (applying the "custom of the trade that shipping points within an area with equal rates are applicable" in a situation where the parties' confirmations differed in their specification of acceptable shipping points and there was no trade rule on point); Pillsbury Co. v. Louis Dreyfus Corp., NGFA Case Nos. 1568, 1570 (1982) (noting that there were no relevant trade rules, and looking to "trade custom" to determine "the accepted trade practice regarding [the meaning of the] terminology"); Cargill Inc. v. Louis Dreyfus Corp., NGFA Case No. 1566 (1982) (noting that under the terms of the contract it was unclear whether the defendant "had a right to [name] destinations not specified in the contract," and holding that it did, explaining that while there was no trade rule on point "[ $t]$ here seems to be ample precedent in historical trade customs and practices to affirm that the Defendant did have a right to [name] alternative destinations from those originally specified . . . assuming that the Defendant bears . . . 'transportation costs' to do so"); Fred Webb Inc. v. B.M. Hancock \& Sons Feed Mill Inc., NGFA Case No. 1549 (1979) (noting that the contract and the trade rules were silent and that the parties agreed on the content of the relevant custom, the arbitrators took the custom into account); Cargill Inc. v. Williams Grain Co., NGFA Case No. 1522 (1976) (noting that because both the contract and the trade rules were silent on the relevant issues, the arbitration committee "based its decision on the custom of the trade"); Bunge Corp. v. Harold V. Tucker, NGFA Case No. 1517 (1975) (holding, in a situation where there were no applicable trade rules, that " $[t]$ rade customs and practice indicate that truck drivers delivering grain cannot be presumed agents for the principal").

44 See, e.g., Louis Dreyfus Corp. v. Early \& Daniel Co., NGFA Case No. 1547 (1979) (holding that while the plaintiff's buy-in might have been in accord with the "realistic demands and customary understanding of the Evansville corn trade," it was nonetheless improper because it did not accord with the letter of Grain Trade Rule 11); Willow Hill Grain Co. v. Tabor \& Co., NGFA Case No. 1542 (1978) (granting the plaintiff a price adjustment, explaining that " $[w]$ hile defendant may have 'followed the standard grain practice of settling the overfill,' it did not exactly follow Grain Trade Rule 12(f) $)^{n}$.

${ }^{45}$ See, e.g., Attebury Grain Inc. v. Commodities Inc., Texas Grain \& Feed Ass'n Case No. 188 (1991) ("The committee recognizes that it is the custom of the trade to not normally pay premiums for No. 1 Milo, however the terms of the explicit contract take precedence over custom of the trade.").

${ }^{46}$ For example, in Bunge Corp. v. Agri Industries, NGFA Case Nos. 1586, 1587 (1983), the arbitrators agreed with the plaintiff's contention "that situations of this nature [involving weather-related barge delays] are often worked out on an amicable give-and-take-basis." Id. Nevertheless, they held for the defendant-buyers who bought-in the freight and refused to extend the contracts, explaining: 
Despite NGFA's reluctance to rule on the basis of custom, custom does play a number of subsidiary roles in NGFA decisions. Opinions sometimes refer to custom as an additional justification for a result reached on other, independent grounds, most commonly the application of a trade rule. ${ }^{47}$ Arbitrators also use custom to assess the credibility of evidence and oral testimony. ${ }^{48}$ In addition,

The fact that other trades shipped at the same time and in the same geographical area were extended by mutual consent proved that a great deal of good will governs many of our trade relationships. But no one is required to grant such extensions. The fact that some parties did agree to such extensions certainly does not govern as a precedent for other trades.

Id.

There are a few cases where the language of the decision suggests that the arbitrators are ruling on the basis of custom. However, a closer look at the facts of these cases reveals that the same results could easily have been reached on the basis of the trade rules alone. See, e.g., Continental Grain Co. v. Curtis Rodgers, NGFA Case No. 1636 (1986) (dismissing the seller's claim that the buyer had breached the contract by rejecting off-grade grain on the ground that "the custom of the trade is that the buyer reserves the right whether to accept on contract poor-quality or offgrade grain," without mentioning that the buyer's right to accept or reject off-grade goods is clearly established in Grain Trade Rule 17); ConAgra Inc. v. BOS Commodities, NGFA Case No. 1627 (1986) (ruling against a buyer claiming nonconforming tender because he "did not comply with normal industry practice of notifying the seller of its intention to buy-in against the contract," a result that could also have been reached under the trade rules).

${ }^{17}$ See Louis Dreyfus Corp. v. AGP Grain Coop., NGFA Case No. 1703 (1993) (noting that "[i]n reaching a decision, the arbitrators focused on NGFA Grain Trade Rule 31(b)," but also looked to "trade practice," although no particular practice was identified); Louis Dreyfus Corp. v. Farmers Grain Terminal Inc., NGFA Case No. 1663 (1990) (holding that the plaintiff-buyer waived his rights to reject a barge because he did not inspect it "in a timely manner according to the NGFA Trade Rules, the Uniform Commercial Code or the practices of the trade at that time"); FCX Inc. v. Paramount Poultry, Div. of Cargill Inc., NGFA Case No. 1623 (1985) (noting that "[i]n the trade and in official grading, coffeeweed seed is regarded as foreign material"); Tabor Grain Co. v. Ralston Purina Co., NGFA Case No. 1555 (1980) (holding for the defendant and noting that the plaintiff's actions clearly violated NGFA Grain Trade Rule 30 and were "beyond any reasonably accepted trade practice"); Consolidated Grain \& Barge Co. v. Thomas P. Gonzalez Corp., NGFA Case No. 1516 (1975) (holding that the plaintiff's confirmation, which was signed by the defendant, made a particular tariff's loading minimum applicable, but noting as well that the tariff's minimums were also "an accepted trade practice unless otherwise agreed upon").

${ }^{48}$ See, e.g., Indiana Grain Div. of Ind. Farm Bureau Coops. Ass'n v. J \& S Farms Inc., NGFA Case No. 1645 (1988) (discounting the defendant's testimony that it thought it was supposed to directly pay a supplier, rather than the seller, on the grounds that ${ }^{\text {" }}[\mathrm{i}] \mathrm{t}$ is not an industry practice for a buyer to bypass the party that sold it grain so as to pay a third firm that was in line as a supplier" ); DeBruce Grain Inc. v. Cargill Inc., NGFA Case No. 1635 (1986) (attempting, in face of contradictory evidence, to establish the date that a bill of lading was issued, the arbitrators took into account "the custom of the trade [which] dictated that the earliest date of a bill 
opinions sometimes discuss custom in an effort to signal the arbitrators' view of the propriety of the parties' contracting behavior. ${ }^{49}$ When the arbitrators are convinced that the trade rules either do not reflect a common trade usage ${ }^{30}$ or are unworkable in practice, ${ }^{51}$ they will note this in their opinion along with a suggestion that the Trade Rules Committee consider amending the trade rules. The rules are sometimes amended following such notations. ${ }^{32}$

NGFA arbitrators may, however, implicitly take custom into account in a way that cannot be detected by reading arbitration opinions. Because NGFA arbitrators are experienced industry members, it is likely that in interpreting contractual language they instinctively give particular terms their "meaning in the trade" when such a meaning truly exists.

of lading would be the load date of the barge and the latest date of a bill of lading would be [the] pick-up date of the barge"); R.F. Cunningham \& Co. v. Pennfield Corp., NGFA Case No. 1544 (1978) (holding that the plaintiff who had provided the weight certificate required by the contract was entitled to be paid on the basis of the certificate because it "faithfully fulfilled its part of the contract," while the weighing method that the defendant used to attempt to establish a shortfall was suspect because it was not even an "accepted trade practice").

${ }^{49}$ See, e.g., Continental Grain Co. v. Pingree Grain Co., NGFA Case No. 1554 (1980) (awarding the plaintiff damages for canceled contracts, but noting that "[b]oth parties condoned and practiced a procedure of posting/applying deliveries against contracts that violated standard methods customarily used by the trade").

${ }^{50}$ See Pillsbury Co. v. Cook Indus., NGFA Case No. 1530 (1977) ("If trade practices are changing, consideration should be given to update the rules to reflect such changes."); Cook Indus. v. Pillsbury Co., NGFA Arb. App. Case No. 1530 (1977) ("It is our collective opinion that the letter of the [trade] rule reigns . . . . We recommend [that] dissensions with the rules manifest themselves before the fact at the appropriate forums conducted with regularity by the Trade Rules Committee.").

${ }^{51}$ See Pioneer Hi-Bred Int'l Inc. v. Overby Grain Farms Inc., NGFA Case No. 1700 n.1 (1993) (" $[T]$ he arbitrators have communicated to the NGFA's Trade Rules Committee the dichotomy posed by NGFA Barge Trade Rule $2(\mathrm{~g})(1)$ as it is now written. The unloading buyer has the obligation to report the weight back to the original shipper. But the original shipper may not have the contractual relationship with the unloading buyer that would permit enforcement should the rule not be followed."); Guthrie Corp. v. Continental Grain Co., NGFA Case No. 1673 n.1 (1992) ("The arbitrators believed that the NGFA's Trade Rules Committee should examine whether a more specific definition of 'due diligence' in the Trade Rules would minimize future disputes of this nature, and have communicated this view to the committee.").

${ }^{52}$ For example, the Barge Trade Rule at issue in Cook Industries v. Pillsbury Co. was subsequently amended. See supra note 33. 


\section{Course of Performance and Course of Dealing}

NGFA's attitude towards taking course of dealing and course of performance $^{33}$ into account is even more restrictive than its attitude towards custom. Neither the trade rules nor NGFA's common law hierarchy of authority mention course of dealing or course of performance. ${ }^{54}$ Although arbitrators occasionally take course of dealing or course of performance into account in filling contractual gaps, ${ }^{53}$ these considerations are seldom the explicit basis for arbitral decisions. ${ }^{36}$ In fact, some opinions have either implicitly or explicitly excluded them as a basis of decision. ${ }^{37}$

${ }^{53}$ The discussion of NGFA's approach to course of dealing and course of performance is based on all of the NGFA opinions from 1975 to 1994 that the Author classified as either explicitly or implicitly referring to these considerations.

${ }^{34}$ The only Grain Trade Rule that could be interpreted as referencing course of dealing is Grain Trade Rule 2, which provides, in part, that "in cases where the Buyer and Seller have been trading on agreed terms and conditions . . . it shall be sufficient for the words 'usual terms' to be used in confirmation, and the use of said words shall imply that such terms and conditions as governed previous trades of a like character shall apply." Over the past 20 years there have been no cases addressing the question of whether the phrase "usual terms" includes course of dealing and/or course of performance. However, because transactors must explicitly opt-in to this rule, it certainly does not make these considerations relevant to contract interpretation more generally. In addition, transactors rarely conclude deals under this section because they fear that arbitrators will interpret the rule to include course of dealing and course of performance, which would, in their view, make the terms of the deal far too uncertain. See Interview with Grain Company Executive (Sept. 1995).

55 See National Farms Inc. v. Bearhouse Inc., NGFA Case No. 1589 (1983) (noting that the contracts "did not specify the type of weights or grades to be furnished," the arbitrators implicitly ruled on the basis of course of dealing, explaining that because "[p]revious trades were completed on destination terms ... [such terms] must be assumed in this case").

${ }^{36}$ In one highly unusual case, however, a course of performance was found to trump an explicit contractual provision. In Rickel Inc. v. Agra Grain Corp., NGFA Case No. 1665 (1990), one issue was whether particular shipments of corn were within the grade specifications of the contract. Although the contract contained a provision specifying a minimum acceptable grade of corn and many of the shipments whose quality was at issue were indisputably below this grade, the arbitrators found the corn to be applicable on the contract. They explained that before the dispute arose and relations between the parties deteriorated, there was "no evidence to suggest that any loads [of below contract grade corn] were rejected," and that, as a consequence, "[t]he behavior of the parties indicated that the minimum grade specified in the contract did not actually apply." Id. One possible explanation for the arbitrators' willingness to deviate from the established rule of giving primacy to the express terms in a contract in this case is that the minimum grade clause in the contract was so unusual that the arbitrators found it unlikely, particularly in face of their contrary actions, that the parties intended the term to have its apparent meaning. See Interview with Grain Company Executive (Sept. 1995).

${ }^{37}$ See, e.g., Peavey Grain Co. v. Cargill Inc., NGFA Case No. 1669 (1991) (rejecting 
Nevertheless, course of dealing and course of performance do play a role in NGFA arbitrations. They are sometimes taken into account in assessing the credibility of evidence or testimony, ${ }^{58}$ and are occasionally mentioned in opinions as additional justifications for results that the arbitrators can or do justify on other, independent grounds. ${ }^{39}$

On occasion, the arbitrators give weight to a type of contextual evidence that does not fit neatly into any of the Code's categories: namely, evidence that a party has an established business practice that it routinely follows in particular types of transactions. When evidence of an established business practice is presented, it creates a strong, although not irrebuttable, presumption that the party followed the practice in the particular case. ${ }^{60}$

\section{B. The Code's Adjudicative Approach}

On a formal level, the Code's hierarchy of authority is similar to NGFA's. The Code accords the greatest weight to "express terms of an agreement," followed by course of performance, ${ }^{61}$

the seller's suggestion that the buyer should be compelled to accept a lesser-quality grade certificate on the second shipment because he had done so on the first shipment); Tabor \& Co. v. Cargill Inc., NGFA Case No. 1520 (1976) (noting that the defendant used a less reliable type of inspection than was provided for in the contracts, the arbitrators gave no weight to the "submitted proof that [the plaintiff] had accepted such inspections on other barges before, during and after the period of occurrence").

${ }^{58}$ See, e.g., Little Egypt Grain Co. v. Consolidated Grain and Barge Co., NGFA Case No. 1674 (1991) (finding the plaintiffs claim not to have received the defendant's confirmation not credible, in part because ' [ $t]$ he parties' prior course of dealing with one another revealed that the defendant had sent confirmation letters ... in the past ... [in this type of transaction, but that] the plaintiff . . . did not routinely send confirmations ... . in ... dealings between the parties").

${ }^{59}$ See, e.g., Fred Webb Inc. v. Cargill Inc., NGFA Case No. 1691 (1993) (noting that the parties' contract was vague, calling only for "destination' grades," the arbitrators held for the defendant on the ground that it had provided a type of destination grade and that the type of grade it submitted had been used "to settle shipments in prior trades").

${ }^{60}$ See, e.g., Fred Webb Inc. v. General Mills Inc., NGFA Case No. 1583 (1982) (where seller signed without objection buyer-mill's confirmation, which required the wheat to be of "milling quality," and a dispute arose as to the meaning of the term, the arbitrators found the buyer-miller's more stringent definition of "milling quality" to be applicable, explaining that " $[\mathrm{i}] \mathrm{t}$ is customary practice for mills to set standards in buying wheat with commercially more stringent requirements than those determined to be actionable by the FDA").

${ }^{61}$ See U.C.C. $\$ 2-208(1)$ ("Where the contract for sale involves repeated occasions for performance by either party with knowledge of the nature of the performance and opportunity for objection to it by the other, any course of performance accepted or 
course of dealing, ${ }^{62}$ usage of trade, ${ }^{63}$ and, finally, the Code's own gap-fillers. ${ }^{64}$ In practice, however, unlike NGFA arbitrators, courts, in a variety of doctrinal guises that are either explicitly or implicitly authorized by the Code, ${ }^{65}$ often allow these considerations to

acquiesced in without objection shall be relevant to determine the meaning of the agreement.").

${ }^{62}$ See id. $\$ 1-205(1)$ ("A course of dealing is a sequence of previous conduct between the parties to a particular transaction which is fairly to be regarded as establishing a common basis of understanding for interpreting their expressions and other conduct.").

${ }^{63}$ Under the Code, a trade usage is "any practice or method of dealing having such regularity of observance in a place, vocation or trade as to justify an expectation that it will be observed with respect to the transaction in question." Id. § 1-205(2). A trade usage need not be universally followed. "[F]ull recognition is . . . available for ... usages currently observed by the great majority of decent dealers, even though dissidents ready to cut corners do not agree." Id. $\$ 1-205 \mathrm{cmt}$. 5 . The existence and scope of a usage are to be proved as fact. This is ordinarily done through the introduction of affidavits or testimony from industry experts. See, e.g., Harlow \& Jones, Inc. v. Advance Steel Co., 424 F. Supp. 770, 773 (E.D. Mich. 1976) (introducing the testimony of two employees and "two disinterested local steel importers" in an effort to establish "an accepted steel importing trade usage . . . [that] shipment in September-October means delivery in October-November" ${ }^{\prime}$ ). It may also be done through introduction of a trade code or industry-promulgated qualitystandards specifications. See U.C.C. $\$ 1-205 \mathrm{cmt} .5$ (noting that "there is room ... for proper recognition of usage agreed upon by merchants in trade codes"); Foxco Indus. v. Fabric World, Inc., 595 F.2d 976, 985 (5th Cir. 1979) (noting that the Knitted Textile Association's standards were a trade usage because "uncontroverted testimony" established that the association was "an industry group with over 1500 members"). It is, however, important to note that the mere existence of a trade code is not enough to establish a usage. See, e.g., JAMES J. WhITE \& ROBERT S. SUMMERS, UNIFORM COMMERCIAL CODE \$ 3-3, at 140 \& nn.40-41 (3d practitioners' ed. 1988) (discussing the complications that may arise when trade codes are introduced to establish usages and citing cases).

${ }^{64}$ See U.C.C. \$ 1-205(4) ("The express terms of an agreement and an applicable course of dealing and usage of trade shall be construed wherever reasonable as consistent with each other; but when such construction is unreasonable express terms control both course of dealing and usage of trade and course of dealing controls usage of trade."); id. § 2-208(2) ("E]]xpress terms shall control course of performance and course of performance shall control both course of dealing and usage of trade ... ."); id. \$ 1-205 cmt. 4 (explaining that "those rules of law (such as those in Part 3 of Article 2 on Sales) which fill in points which the parties have not considered and in fact agreed upon ... yield to contrary agreement of the parties ... [ [which includes] the usages of trade which furnish the background and give particular meaning to the language used, and are the framework of common understanding controlling any general rules of law which hold only when there is no such understanding").

${ }_{65}$ See, e.g., id. \$ 1-205(3) ("A course of dealing between parties and any usage of trade .. . [should be used to] give particular meaning to and supplement or qualify the terms of an agreement."); id. § 2-208(1) ("[A]ny course of performance accepted or acquiesced in without objection shall be relevant to determine the meaning of the agreement."). 
vary or trump the express terms of a written contract. In some instances these considerations are permitted to take precedence over express terms on the grounds that they do not contradict, but rather clarify, qualify, or supplement, the express terms of the written agreement. ${ }^{66}$ In other instances, such as where the contract's express provisions are silent on an issue or the agreement itself was formed through a course of performance, these considerations are sometimes found to supply additional contractual provisions. ${ }^{67}$ In addition, they are frequently introduced to establish an industry-specific meaning of a word or phrase that may or may not have a clear lay meaning. ${ }^{68}$ The industry-specific meaning is then given precedence over the lay meaning. Finally,

${ }^{66}$ In Nanakuli Paving \& Rock Co. v. Shell Oil Co., 664 F.2d 772 (9th Cir. 1981), a contract for the sale of asphalt contained an explicit provision which stated that the seller's posted price at the time of delivery would govern. However, the buyer claimed that it was entitled to "price protection" under a usage of the asphalt-paving trade in Hawaii that required the seller to sell at the original price all the asphalt that the buyer had committed to use in jobs on which it had already bid in reliance on the seller's price. See id. at 777. The court held for the buyer, explaining that "the jury could have reasonably construed price protection as consistent with the express term." Id. at 780; see also Columbia Nitrogen Corp. v. Royster Co., 451 F.2d 3, 7 (4th Cir. 1971) (holding that, despite express price and quantity terms and a standard integration clause, evidence to show that it was a custom and usage of the fertilizer industry that "express price and quantity terms in contracts for materials in the mixed fertilizer industry are mere projections to be adjusted according to market forces" was admissible to establish a consistent additional term to the parties' written contract); American Mach. \& Tool Co.v. Strite-Anderson Mfg. Co., 353 N.W.2d 592, 597 (Minn. Ct. App. 1984) ("The trend has been for judges, looking beyond written contract terms to reach the 'true understanding' of the parties, to extend themselves to reconcile trade usage and course of dealing with seemingly contradictory express terms. They have permitted course of dealing and usage of trade to add terms, cut down on or subtract terms, or lend special meaning to contract language."); Modine Mfg. Co. v. North E. Indep. Sch. Dist., 503 S.W.2d 833, $837-38$ (Tex. Ct. App. 1973) (holding that although the contract provided that air-conditioning cooling "capacities shall not be less than indicated," it was nevertheless reversible error to exclude evidence that in the air-conditioning industry it was customary for "reasonable variations in cooling capacity [to be] considered to comply with specifications"); WHITE \& SUMMERS, supra note 63, \$ 3-3, at 136 (concluding that "the provision that express terms control inconsistent course of dealing and its cohorts [namely, course of performance and usage of trade] really cannot be taken at face value, at least in some courts").

${ }^{67}$ See, e.g., Varni Bros. Corp. v. Wine World, Inc., 41 Cal. Rptr. 2d 740, 745-46 (1995) (finding that "there was some form of implied-in-fact operating contractual agreement" that arose from the parties' "course of conduct," the court held that evidence of usage of trade was admissible to establish a term of the contract, but granted summary judgment for the defendant on the ground that the evidence offered to establish the usage was "insufficient to raise a triable issue of fact").

${ }^{68}$ See, e.g., Foxco Indus. v. Fabric World, Inc., 595 F.2d 976, 984 (5th Cir. 1979) (looking to trade usage to define the term "first quality goods"). 
because the Code provides that "course of performance shall be relevant to show a waiver or modification of any term inconsistent with such course of performance, ${ }^{, 69}$ course of performance may have the effect of removing an express written term from an agreement.

Course of performance, course of dealing, and usage of trade also influence commercial adjudication through a host of other Code provisions that direct courts to look to commercial practices, ${ }^{70}$ and through the Code's "good faith" provision, ${ }^{71}$ which, as the Official Comment notes, "directs a court towards interpreting contracts within the commercial context in which they are created, performed and enforced."72

On a formal level, the Code gives transactors a way to limit the applicability of these provisions, but in practice it is difficult for them to do so with sufficient certainty. Transactors may contract around a usage by specifically negating the usage, ${ }^{73}$ but simply including a specific term dealing with the same aspect of the contracting relationship as the usage is insufficient to negate it. $^{74}$

${ }^{69}$ U.C.C. § 2-208(3); see also WHITE \& SUMMERS, supra note 63 , § 1-6, at 67 ("[I]f, in light of a 'relevant' course of performance, either a waiver or a modification ... is . . . shown, it is not inappropriate to say that course of performance 'controls' and thus alters the express term."). The Official Comment to UCC $\$ 2-208$ creates a bias towards interpreting a course of performance as a waiver. It provides that " $[w]$ here it is difficult to determine whether a particular act merely sheds light on the meaning of the agreement or represents a waiver of a term of the agreement, the preference is in favor of 'waiver' whenever such construction . . . is needed to preserve the flexible character of commercial contracts." U.C.C. \$ 2-208 cmt. 3.

${ }^{70}$ See supra note 2 (citing Code provisions).

${ }^{71}$ U.C.C. $\$ 1-203$. Because the Code provides that the duty of good faith cannot be "disclaimed by agreement," $i d . \S 1-102(3)$, and the Official Comment provides that the good faith provision is to be "implemented by Section 1-205 on course of dealing and usage of trade," id. $\S 1-203 \mathrm{cmt}$., it is unlikely that transactors will be able to entirely contract out of the Code's approach to adjudication.

${ }^{72}$ Id. $\$ 1-203 \mathrm{cmt}$.

${ }^{73}$ See id. $\$ 2-202 \mathrm{cmt} .2$ ("Unless carefully negated, [usages of trade] have become an element of the meaning of the words used.").

${ }^{71}$ See, e.g., Nanakuli Paving \& Rock Co. v. Shell Oil Co., 664 F.2d 772, 805 (9th Cir. 1981) (permitting a usage to be introduced to vary an explicit contract provision dealing with the same aspect of the transaction as the usage); Columbia Nitrogen Corp. v. Royster Co., 451 F.2d 3, 10-11 (4th Cir. 1971) (same); Modine Mfg. Co. v. North E. Indep. Sch. Dist., 503 S.W.2d 833, 840 (Tex. Ct. App. 1973) (same). Courts' reluctance to find that express written provisions negate a usage dealing with the same aspect of the transaction as the written provision may be due, in part, to UCC § 1-205(4), which provides that " $[t]$ he express terms of an agreement and an applicable ... usage of trade shall be construed wherever reasonable as consistent with each other." Id. 
Similarly, while the Code explicitly permits transactors to include a provision that "excludes modification or rescission except by a signed writing,"75 courts sometimes permit the provisions themselves to be modified by a course of performance. ${ }^{76}$ In addition, courses of performance that do not amount to modifications are sometimes held to be waivers. ${ }^{77}$ Although transactors can retract a waiver of an executory portion of the contract by "reasonable notification," unless doing so "would be unjust in view of a material change of position [by the other transactor] in reliance on the waiver, ${ }^{\text {78 }}$ it is difficult to predict when courts will find reliance. Furthermore, even if the waiver is properly retracted, the course of performance may remain "relevant to determine the meaning of the agreement. ${ }^{79}$

75 U.C.C. § 2-209(2).

${ }^{76}$ See, e.g., Linear Corp. v. Standard Hardware Co., 423 So. $2 d$ 966, 968 (Fla. Dist. Ct. App. 1982) (holding, despite a clear provision requiring all modifications to be in writing, that "the parties to a contract may modify the written agreement by subsequent oral agreement or course of dealing with one another despite the requirement of a writing in order to modify," and here "the evidence as to the parties' conduct supports finding both a waiver of the requirement that subsequent modifications be in writing signed by both parties and that a subsequent modification occurred"); see also Fairfax Leary, Jr. \& David Frisch, Uniform Commercial Code Annual Survey: General Provisions, Sales, Bulk Transfers, and Documents of Title, 39 BUS. LAw. 1851,1861 (1984) ("If the parties agree in writing that they will modify their agreement only by a written modification, they ought not be able to modify orally. However, the waiver provision in UCC section 2-209(4) is so broad that it virtually nullifies such a clause in the written contract. Moreover, the parties' post-contracting conduct can indicate their mutual intent to modify ....").

77 See, e.g., Wisconsin Knife Works v. National Metal Crafters, 781 F.2d 1280, 1287 (7th Cir. 1986) (holding, in face of a no-oral-modification clause, that an attempt to modify the contract through conduct could operate as a waiver if the promisor "has actually incurred a cost, has relied"); Knoxville Rod \& Bearing, Inc. v. Bettis Corp., 672 S.W.2d 203, 208 (Tenn. Ct. App. 1983) (noting that the contract contained a clause prohibiting modifications not in writing, the court held that while defendant's course of performance could not constitute an enforceable modification, it nevertheless did amount to a waiver); see also Westinghouse Credit Corp. v. Shelton, 645 F.2d 869, 873 (10th Cir. 1981) ("[T]he weight of authority . . . is that an 'antiwaiver' clause, like any other term in the contract, is itself subject to waiver or modification by course of performance and that whether such a waiver or modification has occurred is a question for the fact-finder."); U.C.C. $\$ 2-209 \mathrm{cmt} .4$ ("Subsection (4) [dealing with modification] is intended, despite the provisions of subsections (2) [authorizing clauses requiring modifications to be in writing] and (3) [statute of frauds] to prevent contractual provisions excluding modification except by a signed writing from limiting in other respects the legal effect of the parties' actual later conduct. The effect of such conduct as a waiver is further regulated in subsection (5).").

${ }^{78}$ U.C.C. $\$ 2-209(5)$.

${ }^{79}$ Id. $\S 2-208(1)$. 
Thus, there are a number of ways that courts permit course of performance, course of dealing, and usage of trade to trump express written terms and limit transactors' ability to reliably exclude these considerations from the interpretive process. Although some courts give greater emphasis to the contract's written terms, ${ }^{80}$ their decisions are in tension with the Code's underlying adjudicative approach, its definition of agreement, its broad "duty of good faith," and its lax version of the parol evidence rule, which permits these considerations to be introduced to explain or supplement even a complete and integrated writing. ${ }^{81}$ In practice, the Code's adjudicative approach is far closer to a mandatory, rather than a default, adjudicative approach.

\section{Conclusion}

The striking differences between NGFA's adjudicative philosophy, a philosophy chosen by sophisticated merchant-transactors, and the philosophy embedded in the Code, a philosophy Llewellyn designed to be accommodating to merchant concerns, suggests that it would be interesting to consider the reasons that sophisticated merchant-transactors might find it advantageous to opt for a NGFAtype adjudicative philosophy.

\section{The Theory OF Legally UNENForceable AgREEMENTS}

In order to understand why sophisticated merchant-transactors might find a NGFA-type adjudicative philosophy desirable, it is useful to focus on an observation that has been documented in the law and society literature, namely that the contours of transactors' contracting relationship may not be the same as the scope of the rights and duties memorialized in their written, legally enforceable contract. ${ }^{82}$ In many contexts, transactors accept late payment, vary

${ }^{80}$ See Southern Concrete Servs., Inc. v. Mabelton Contractors, Inc., 407 F. Supp. 581, 583-84 (N.D. Ga. 1975) (noting that the "contract set[] out fairly specific quantity, price, and time specifications," the court held that "to allow such specific contracts to be challenged by extrinsic evidence might jeopardize the certainty of the contractual duties which parties have a right to rely on," explaining that "[c]ertainly customs or trade should be relevant to the interpretation of certain terms of a contract . . . but this court does not believe that Section 2-202 was meant to invite a frontal assault in the essential terms of a clear and explicit contract"), aff'd, 569 F.2d 1154 (5th Cir. 1978).

${ }^{81}$ See U.C.C. § 2-202 \& cmts.; see also WHITE \& SUMMERS, supra note 63, § 2-10, at 115 (discussing the parol evidence rule).

${ }^{82}$ See, e.g., 1 STEWART MACAULAY ET Al., CoNTRACTS: LAW IN ACTION 512 (1995) 
quantity terms, assume new obligations, waive covenants, and adjust prices in ways that their written contracts do not require. They may be moved to do so by social norms, commercial custom, a "concern for relationships, trust, honor and decency, ${ }^{n 33}$ or fear of nonlegal sanctions such as reputational damage or termination of a beneficial relationship. ${ }^{84}$ In some instances, these actions may be responses to new circumstances, while in others they may reflect transactors' decisions to abide by the extralegal commitments that supplement their written contracts. This Part discusses the reasons that rational transactors might deliberately leave aspects of their contracting relationship to be governed, in whole or in part, by extralegal commitments and sanctions. If transactors either act or intend to act in ways that differ from their understanding of the express terms of their written contract, their actions are no longer, as the Code assumes, an accurate guide to their view of the meaning of their written agreement.

In structuring their contracting relationship, transactors allocate aspects of their relationship between the legal and extralegal realms in ways that seek to maximize the value of their transaction. ${ }^{85}$

(presenting evidence from interviews with business people in a wide variety of industries to substantiate the observation that "[e]ven where lawyers prepare elaborate contractual documents, often the business people who carry out the transaction follow conventional practices rather than reading the written contract"); Stewart Macaulay, Non-Contractual Relations in Business: A Preliminary Study, 25 AM. Soc. REv. 55 (1963) [hereinafter Macaulay, Preliminary Study] (discussing the ways that manufacturing firms and their buyers depart from the terms of their express contracts in their everyday interactions); Rock \& Wachter, supra note 10 (noting that employers systematically act in ways that are not required by their at-will employment contracts with their employees); James J. White, Contract Law in Modern Commercial Transactions: An Artifact of Twentieth Century Business Life?, 22 WASHBURN L.J. 1 (1982) (noting that in a time of shortage in the chemical industry, chemical companies arguably did not allocate their production strictly in accordance with the dictates of UCC $\S \mathbf{2 \cdot 6 1 5}$, but rather in accord with other aspects of the underlying transactional relationships).

${ }^{83}$ Jay M. Feinman, Relational Contract and Default Rules, 3 S. CAL. INTERDISC'Y L.J. 43, 52 (1993).

${ }^{84}$ See Charny, Nonlegal Sanctions, supra note 10, at 379-90 (giving an overview of nonlegal sanctions).

${ }^{85}$ See Benjamin Klein, Transaction Cost Determinants of "Unfair" Contractual Arrangements, 70 AM. ECON. REV. 356, 358 (1980) ("Most actual contractual arrangements consist of a combination of explicit- and implicit-enforcement mechanisms. Some elements of performance will be specified and enforced by thirdparty sanctions. The residual elements of performance will be enforced without invoking the power of some outside party to the transaction but merely by the threat of termination of the transactional relationship. The details of any particular contract will consist of forms of these general elements chosen to minimize transaction 
Sometimes transactors allocate aspects of their contracting relationship to the extralegal realm because the transaction costs of including a sufficiently well-specified written provision in their contract would exceed the benefits. ${ }^{86}$ Other times, they do so because nonlegal sanctions such as reputation bonds are strong enough in the relevant market to ensure that an obligation will be performed, making a legally enforceable provision unnecessary.

Transactors may also fail to include written provisions dealing with a particular contingency because each may fear that the other will interpret a suggestion that they do so as a signal that the transactor proposing the provisions is unusually litigious or likely to resist flexible adjustment of the relationship if circumstances change. ${ }^{87}$ These potential relational costs of proposing additional explicit provisions may result in aspects of a contracting relationship

costs.").

${ }^{86}$ In some contexts, however, the transaction costs of entering into an extralegal agreement might be greater than the transaction costs of entering into a legally enforceable contract.

Because the ability of the promisee to enforce an extralegal contract [often] depends on the posting of a reputation bond by the promisor, each of the parties must bear the 'information cost' of determining whether the other party is trustworthy before negotiation over the terms of the agreement even begins. This cost may be substantial and will depend, at least in part, on the size, structure, and terms of the proposed transaction as well as on the likelihood that the parties will have occasion to deal with one another again in the near future. In general, the magnitude of precontract transaction costs incurred in the formation of extralegal contracts will depend on how common such contracts are in the relevant market.

Lisa Bernstein, Opting Out of the Legal System: Extralegal Contractual Relations in the Diamond Industry, 21 J. LEGAL STUD. 115, 132-33 (1992) [hereinafter Bernstein, Diamonds].

${ }^{87}$ In some contracting contexts, transactors approach the task of reducing their relationship to a written contract

with an idea of how similar transactions are usually structured; they have in their minds an implicit form contract made up of clauses such as price that are commonly negotiated, boilerplate provisions, . . . legal default rules [and extralegal provisions]. A party may be wary of suggesting too many deviations from the implicit form contract since this might be interpreted as a signal that he is a less reliable or more contentious trading partner than the average market participant .... [T] [his signal might, in turn, lead the other party to either propose additional provisions or demand a price adjustment to compensate him for the added perceived risk that a dispute will arise. It might also increase the risk of transaction breakdown as well as the likelihood that the transaction will not be consummated by the relevant deadline.

Lisa Bernstein, Social Norms and Default Rules Analysis, 3 S. CAL. INTERDISC'Y L.J. 59, 71-72 (1993). 
being allocated to the extralegal realm, particularly in contexts where the post-contract-formation relationship between the transactors is highly relational in nature so that transactors' perceptions of the value of the transaction will be strongly affected by the attitudinal signals sent during pre-contractual negotiation. ${ }^{88}$

Another reason that transactors may allocate aspects of their relationship to the extralegal realm is that the legal system costs of including a provision in their contract are too high. Legal system costs are those costs that arise from the fact that litigation is costly, prone to delay, and subject to judicial error. ${ }^{89}$ In computer software markets, for example, legal system costs are an important reason that both manufacturers and consumers may be better off if shrink-wrap agreements disclaim all warranties and state that no licenses will be granted, but manufacturers promise, in some legally unenforceable way, to fix defective products and grant licenses where appropriate. As one manufacturer whose shrink-wrap contained broad warranty disclaimers and restrictive license provisions explained:

[M]ost software houses are willing to be less restrictive in practice, but with suits being brought for almost any reason, valid and otherwise, and with such suits being expensive to defend ... [s]oftware houses will probably continue to use similar wording in warranties and licenses, if for no other reason than to avoid attorney fees rather than responsibility. ${ }^{90}$

In this context, if manufacturers used provisions that stated more precisely when licenses would be granted and the software repaired, the legal system costs associated with these provisions would increase the price of the product. The provisions would increase

${ }^{88}$ As one grain merchandiser explained, "there are some aspects of a deal that aren't written down because there is a sense that they are better dealt with as gentlemen on an as-needed basis. I would be reluctant to deal with someone who wanted to include such things in his confirmatory memoranda." See Interview with Grain Merchandiser (Mar. 1996).

${ }^{89}$ For a comprehensive discussion of legal system costs and their effect on the drafting of commercial contracts, see Edward A. Bernstein, Law E Economics and the Structure of Value Adding Contracts: A Contract Lawyer's View of the Law E Economics Literature, 74 OR. L. REV. 189 (1995).

${ }^{90}$ R. David Otten, Warranty Pirates, BYTE, Mar. 1983, at 22, 22 (letter to the editor). This incident was first discussed in Charles J. Goetz \&e Robert E. Scott, The Limits of Expanded Choice: An Analysis of the Interactions Between Express and Implied Contract Terms, 73 CAL. L. REV. 261, 272 n.24, 295-96 (1985) (recounting this incident as "a classic example of the use of ill-fitting formulations" that are often included in contracts primarily because their meaning has been clearly established through litigation). 
the likelihood that manufacturers would have to defend against nuisance suits and would create a substantial risk that, even if a manufacturer met its obligations, a court might err and force it to pay a large judgment. Legal system costs would also make such provisions of limited benefit to consumers, who would, in most instances, find them prohibitively expensive to enforce. In the software market, the trade press makes it relatively easy for consumers to get information about manufacturers' reputations for repairing their products and granting licenses. As a consequence, both manufacturers and consumers may prefer lower-priced software with broad disclaimers and the manufacturer's extralegal, reputation-bond-backed promise to grant licenses and repair products in appropriate circumstances to higher-priced software with detailed, legally enforceable warranty and license provisions. In general, the potential legal system costs created by the use of written contractual provisions are an important reason that transactors may prefer to deal with aspects of their relationship through extralegal agreements.

Finally, one of the most important reasons that transactors allocate aspects of their agreement to the legal or extralegal realm turns on the distinction between observable and verifiable information. Observable information is information that it is both possible and worthwhile for transactors to obtain. Verifiable information is information that it is worthwhile for transactors to prove to a designated third-party neutral in the event of a dispute. ${ }^{91}$ Transactors will only find it worthwhile to include written provisions in their contract that condition on information that is both observable and verifiable. ${ }^{92}$ Provisions that would condition on information that is only observable would be allocated to the extralegal realm. In many contracting contexts, particularly those where nonlegal sanctions are effective, transactors can make their contracting relationship more complete, and hence more valuable, by supple-

${ }^{91}$ See Alan Schwartz, Relational Contracts in the Courts: An Analysis of Incomplete Agreements and Judicial Strategies, 21 J. LEGAL STUD. 271, 279 (1992).

${ }^{92}$ Although most information that is verifiable is also observable, some verifiable information may not be observable. For example, while the lost-profits component of expectation damages may be verifiable by a court with the power to compel discovery, it may not be observable by transactors attempting to cooperatively resolve a dispute outside of litigation. This may be one reason that in settling disputes among themselves, transactors often settle for reliance damages even though they have entered into contracts that entitle them to recover expectation damages. See infra notes $113-14$ and accompanying text. 
menting their written contract with extralegal provisions that condition on observable information and cover additional contingencies.

Consider, for example, a contract obligating a tool and die maker $(S)$ to produce and sell specially manufactured toy-machine attachments to a toy manufacturer $(B)$, who will use the attachments to adapt his basic machinery to produce different types of toys. ${ }^{93}$ Suppose that the attachments may break due to either operator error or a defect in the attachment, that $S$ is the lowest-cost provider of repairs, and that while both $S$ 's repair technicians and $B$ 's machine operators can determine the cause of a particular breakdown with reasonable accuracy, it would be difficult and/or expensive to establish the cause of a particular breakdown in court. $^{94}$ In such a situation, it would be desirable for $S$ to both produce and repair the attachments. However, a legally enforceable provision requiring $S$ to repair all breakdowns for free might not give $B$ an adequate incentive to prevent operator error, and a provision requiring $B$ to pay for all repairs might not give $S$ an adequate incentive to produce well-made attachments. Ideally, the transactors would like to include a repair provision in their contract obligating $S$ to repair breakdowns due to defects at no charge and breakdowns due to operator error at its usual repair fee. However, because the cause of a particular breakdown is unverifiable-that is, it cannot be proven in court with sufficient accuracy at a reasonable cost-it will not be desirable for the transactors to include a legally enforceable repair provision that makes their respective obligations conditional on the cause of a breakdown. Nevertheless, because the cause of a breakdown is observable, the transactors may find it desirable to enter into a legally enforceable contract without a repair provision and to supplement it with a legally unenforceable

${ }^{93}$ This stylized example is loosely based on the United Shoe Machinery Corporation's contracting practices, which provide a real-world illustration of the ways that legal system costs and the distinction between observable and verifiable information affect the choice of contract terms and transaction structure. See Scott E. Masten \& Edward A. Snyder, United States Versus United Shoe Machinery Corporation: On the Merits, 36 J.L. \& ECON. 33, $62-63$ (1993) (discussing the reasons why United Shoe leased many of its machines to shoe manufacturers and routinely repaired the machines when they broke, even though the leases did not obligate them to do so).

94 The cause of a breakdown may be unverifiable because courts have limited knowledge about machine repairs, the existence of the dispute means that the two witnesses with the best information are likely to give contradictory testimony, and evidence might be difficult to preserve because the machinery must promptly be repaired and returned to use. 
agreement containing the same terms as the ideal repair provision. Assuming that toy manufacturers frequently buy attachments from the same tool and die maker, $S$ 's desire to retain $B$ 's business would give him an incentive to repair all broken attachments but to charge $B$ only when the breakdown was due to operator error. Conversely, $B$ would have an incentive to pay for all repairs necessitated by operator error. If $B$ did not pay for repairs in appropriate circumstances, $S$ might refuse to do business with him in the future. $B$ would then have to bear the costs of switching to another tool and die maker who knows less about $B$ 's production processes and basic machinery, and about whose reputation for making repairs $B$ has little or no information. Thus, by conditioning on observable but unverifiable information, the extralegal repair agreement, supported by the nonlegal sanction of each transactor's threat to terminate a mutually beneficial relationship, makes the transactors' agreement more complete. It adds value to the transaction because $S$ receives a higher price for his machines than he would in the absence of the agreement and $B$ receives repairs from the cheapest, and perhaps best, provider of these services.

The distinction between observable and verifiable information also suggests another reason that transactors may want to conclude a deal with two well-developed sets of contractual provisions, one legally enforceable and one purely extralegal. At the outset of a contracting relationship, a transactor may not know if the person with whom he is dealing is trustworthy. Although he would find it ideal to include two sets of written provisions, one that would apply if the transactor turned out to be trustworthy and another if he turned out to be untrustworthy, trustworthiness is not something the contract can condition on because it is unverifiable. As a consequence, the transactor may find it desirable to include terms in the contract that are the best terms if the other transactor turns out to be untrustworthy, while making extralegal commitments, many of which will, over time, ripen into self-enforcing agreements, ${ }^{95}$ that will govern the relationship if the other party turns out to be trustworthy. ${ }^{96}$ In these transactional contexts, the

${ }^{95} \mathrm{~A}$ contract is said to be self-enforcing if a promisor who is contemplating breach would, upon reflection, find it in her own best interest to perform rather than breach, even in the absence of sanctions imposed by a third party. See Benjamin Klein \& Keith B. Leffler, The Role of Market Forces in Assuring Contractual Performance, $89 \mathrm{~J}$. POL. ECON. 615 (1981).

${ }_{96}$ Consider, for example, a feed transaction where at the outset a buyer $(B)$ does not know if the seller $(S)$ with whom he is dealing is trustworthy. In such a situation, 
written contract functions as a "bond," while the extralegal relational agreement provides the terms of the contract-governance structure. ${ }^{97}$

Thus, while the Code's adjudicative approach is based on the idea that "the course of actual performance by the parties is considered the best indication of what they intended the[ir] writing to mean, ${ }^{n 8}$ there are a number of reasons that rational transactors may prefer to act or agree to act in ways that they know are different from the rights and obligations memorialized in their written legally enforceable contract. It is therefore important to reconsider the desirability of the Code's definition of agreement by exploring its effects on commercial relationships under the more realistic assumption that there is no necessary relationship between transactors' actions and the intended meaning of the terms of their written contract.

The Code's definition of agreement may impose an efficiency loss on transactors relative to a NGFA-type system that systematically refuses to enforce extralegal agreements. By elevating usage of trade, course of dealing, and course of performance to the status of legally enforceable contract provisions, and commercial context to the status of an over-arching interpretive framework, the Code brings a substantial portion of the extralegal realm of contractual relationships within the purview of legal enforceability. This makes it difficult, if not impossible, for transactors to enter into purely extralegal agreements. If transactors rationally prefer to structure their transaction to include a combination of legal and extralegal obligations, but the Code prevents them from entering into purely extralegal agreements, transactors will be unable to select their

$B$ might find it ideal to include a provision requiring an untrustworthy $S$ to provide a federally supervised weight certificate, and a provision permitting a trustworthy $S$ to provide only his own unsupervised in-house weights, an option that results in significant cost savings because federally supervised weight certificates are expensive to obtain. However, because $S$ 's trustworthiness is unverifiable, $B$ might find it desirable to include a provision in the contract requiring federally supervised weights, the best term if $S$ turns out to be untrustworthy, while making an extralegal commitment to accept $S$ 's in-house weights if $S$ turns out to be, and remains, trustworthy.

${ }_{97}$ The literature on nonlegal sanctions views them as substitutes for, or supplements to, legally enforceable contracts. In many merchant contexts, however, it may be more accurate to view a legally enforceable contract as a set of obligations that define the right to get an award of damages, a bond whose primary function is to enhance the value of the extralegal agreement that specifies the terms the transactors actually want to be performed.

${ }^{98}$ U.C.C. § 2-202 cmt. 2. 
preferred mix of legal and extralegal terms. They may therefore be worse off than they would be in a NGFA-type system.

More specifically, because the risk of adjudicative error is greater when courts enforce extralegal provisions than it is when they enforce written provisions, ${ }^{99}$ the Code's approach may induce transactors to include written provisions memorializing the terms of agreements that they would prefer to be extralegal. Alternatively, if the cost of memorializing the desired extralegal agreement in the written contract would be prohibitively high, perhaps because the extralegal agreement seeks to condition on observable but unverifiable information or because the relational cost of negotiating the relevant language would be significant, the Code's approach may lead transactors to forgo both the explicit contractual provisions and the extralegal agreement, thereby decreasing the total value of the transaction..$^{100}$ Conversely, because the Code's search for the transactors' "bargain in fact" and its contextualized interpretive approach often weaken the force of a contract's written provisions, there may be provisions or types of provisions that transactors would find it worthwhile to negotiate and draft if they would be enforced as written that they would not find it worthwhile to negotiate and draft if they thought a court would interpret the provisions "in context."

Thus, because the Code's broad definition of agreement erodes the distinction between legal and extralegal commitments and prevents transactors from selecting their preferred mix of legal and extralegal terms, it will have undesirable effects on commercial relationships. However, in order to fully understand the ways that the Code's adjudicative approach affects commercial relationships, it is important to look in more detail at the Code's usage of trade, course of performance, and course of dealing provisions. These provisions are at the heart of the Code's interpretive approach and play a central role in the court's search for both "immanent business norms" and the parties' "bargain in fact."

${ }^{99}$ It may be difficult for courts to determine the content of extralegal agreements. Transactors often allocate aspects of their relationship to the extralegal realm precisely because an obligation is difficult to describe with sufficient specificity or conditions on unverifiable information. See supra notes 85-97 and accompanying text.

${ }^{100}$ If, however, an aspect of a contracting relationship is allocated to the extralegal realm only because the negotiating and drafting costs are high, transactors may be better off if, in the event of a dispute, the court enforces their extralegal understanding. 


\section{Trade Usage, Course of Performance, AND COURSE OF DEALING}

The effects of the Code's trade usage, course of performance, and course of dealing provisions on commercial relationships can only be understood by focusing on what courts observe when they attempt to give content to these provisions in a particular case. When courts apply the Code's trade usage provision and look at how a majority of market transactors deal with an issue, or apply the course of dealing or course of performance provisions and look at how particular transactors have dealt with an issue, they will, in many instances, be observing the norms that transactors choose to follow when they cooperatively resolve disputes among themselves and want to preserve their relationship ("relationship-preserving norms," or "RPNs"). Some RPNs are "performance norms," which reflect the implicit extralegal terms transactors have agreed to abide by as long as they continue to trust one another and/or value potential future dealings. Other RPNs are "dispute-resolution norms," 101 norms that transactors follow in attempting to cooperatively resolve disputes in a manner that will not jeopardize future dealings. Even when these RPNs are clear and well-developed, they may be quite different from the terms of transactors' written contracts, which contain the norms that transactors would want a third-party neutral to apply in a situation where they were unable to cooperatively resolve a dispute and viewed their relationship as being at an end-game stage ("end-game norms," or "EGNs"). ${ }^{102}$

There are two types of end-game stages. The first is an absolute end-game where the parties, perhaps because of the action giving rise to the alleged breach, have decided not to deal with one another again. ${ }^{103}$ The second is an end-game round, a situation

${ }^{101}$ When courts look to dispute-resolution norms, they will be observing the norms followed in both relationship-preserving and end-game negotiation. However, to the extent that parties to an end-game dispute anticipate that a court will take customary RPNs into account, they may reach settlements that are strongly influenced, if not determined, by these norms. This further reinforces the apparent prevalence of RPNs in the market.

${ }^{102}$ Even when transactors act in accordance with RPNs, the terms of their legally enforceable contract may influence their behavior. Because the provisions of the contract define the maximum amount that the promisee can recover in the event that she chooses to treat a particular breach as an end-game breach, these provisions will affect whether she finds it worthwhile to treat a particular breach as an end-game breach.

${ }^{103}$ A recent study by Jason Johnston, see Jason Johnston, Discovering Contract: A Game-Theoretic Framework for Inferring Contract Formation Norms from 
where the parties are in a long-term contractual relationship that they wish to maintain, but where one or both of them have committed to following a strategy that binds them to seek application of EGNs under certain circumstances. ${ }^{104} \mathrm{~A}$ transactor might follow a strategy of seeking application of EGNs in an end-game round in order to maintain the credibility of his threat to do so in similar situations in the future. In some contracting contexts, particularly those characterized by repeat dealing or long-term relationships, maintaining a credible threat to invoke EGNs in appropriate circumstances may actually facilitate cooperation.

There are a number of reasons that RPNs are likely to diverge from the EGNs contained in written contracts. First, RPNs may reflect adherence to an aspect of the transactors' agreement that they deliberately allocated to the extralegal realm, perhaps because the obligation that they sought to create conditioned on information that was observable but not verifiable, or because the legal system costs associated with memorializing the obligation in a legally enforceable provision would have been prohibitively high. Second, RPNs may reflect patterns of adjustments that transactors are willing to make at some stages of their contracting relationship but that they are nonetheless unwilling to promise to make. ${ }^{105}$ Third,

Reported Decisions (Jan. 1996) (unpublished manuscript, on file with author), provides evidence that when transactors in continuing or repeat-dealing relationships wind up in court, their relationship is typically at an absolute end-game stage. The study examined decisions under the Code's statute of frauds provision, UCC \$ 2-201, and found support for the hypothesis that when "parties in a continuing relationship involving repeat dealings within a relatively tight-knit commercial or social community ... [have disputes, the $d$ ] isputes between such parties that end up in litigation ... tend to represent end-game situations involving the termination of relationships." Id. It also examined decisions under the Code's "battle of the forms" provision, UCC \$ 2207 , and found that "as the theory would predict, the majority of decisions involving parties with a history of prior dealings do involve ... serious, relationship-ending performance problems." Id.

${ }^{104}$ My study of grain and feed disputes found that traders who arbitrated against one another often viewed their relationship as being at an absolute end-game. However, it also found that when the disputing traders worked for medium or large companies, the companies they worked for did not view themselves as being in an absolute end-game. Rather, they viewed themselves as being in an end-game roundthey were willing to deal with one another again in the future, but the plaintiffcompany nevertheless fought hard for the application of EGNs. As one grain company executive explained and others confirmed, companies sometimes seek strict enforcement of the trade rules and contractual provisions (EGNs) in order to maintain the credibility of their threat to do so in the future, a threat that may be quite important to their ability to maintain long-term cooperative relationships and their ability to routinely obtain reasonable settlements without going to arbitration.

${ }^{105}$ See infra notes $142-43$ and accompanying text. 
RPNs and EGNs may also diverge because RPNs whose effectiveness depends on social or reputational sanctions imposed by members of a particular market or social group ${ }^{106}$ tend to be simpler than the explicit contractual provisions that cover the same aspects of the transaction. In addition, these RPNs often have special features that are designed to enable members of the relevant group to determine whether the norms have been violated. These features may be both unnecessary and excessively costly if mechanisms for third-party fact finding, dispute resolution, and enforcement of judgments are available. Fourth, because the best norm to govern a particular situation often depends on transactors' perception of the likelihood of opportunism, transactors who are in the midst of a cooperative relationship will often find it desirable to follow norms that would be highly undesirable if they thought the likelihood of opportunism was high. Finally, RPNs may diverge from EGNs because there are many adjustments that transactors would be willing to make to preserve a profitable relationship that they would be unwilling to make in the absence of the prospect of future gain.

There is empirical evidence from a variety of contracting contexts that suggests that merchants behave in ways that reflect an implicit understanding of the distinction between end-game and relationship-preserving norms and that they do not necessarily want the RPNs they follow during the cooperative phase of their relationship to be used to resolve disputes when their relationship is at an end-game stage.

In the grain and feed industry, when disputes arise between merchandisers with a long-standing trading relationship, they will ordinarily just "split the difference" in an effort not to damage their relationship. ${ }^{107}$ This is an example of a relationship-preserving dispute-resolution norm. NGFA arbitrators, however, rarely "split the difference." ${ }^{108}$ This aspect of the tribunal's adjudicative

${ }^{106}$ For examples of such relevant groups, see ROBERT C. ELLICKSON, ORDER WITHOUT LAW (1991) (discussing Shasta County norms); Eric Posner, Law, Economics, and Inefficient Norms, 144 U. PA. L. REV. 1697 (1996) (discussing the role of the village gossips). See also Bernstein, Diamonds, supra note 86 (discussing diamond industry norms); Charny, Nonlegal Sanctions, supra note 10, at 404 (noting that "[c]ommitments that parties delegate to enforcement by nonlegal sanctions must satisfy different criteria for explicitness").

${ }^{107}$ See Interviews with 15 Grain Company Executives (June 1995).

${ }^{108}$ When NGFA arbitrators do "split the difference," they are careful to identify some aspect of the dispute that led them to do so, most commonly that both parties violated a trade rule, violated a contract provision, or otherwise behaved improperly. See, e.g., Burmeister Farm Store, Ltd. v. Scoular Grain Co., NGFA Case No. 1699 
approach is widely praised by traders and appears to be the desired EGN. ${ }^{109}$ Similarly, while smaller feed merchandisers who transact primarily on a local or regional basis often include official weight provisions in their contracts, they routinely accept one another's unsupervised in-house weights. ${ }^{110}$ Official weights are expensive, so this practice results in significant transaction cost savings. ${ }^{11}$ The norm of accepting in-house weights is a relationship-preserving performance norm that exists alongside a flatly contradictory explicit contractual provision embodying the desired EGN-a provision requiring official weights.

Stewart Macaulay's 1963 study of the contracting practices of manufacturing firms provides additional evidence that merchants implicitly distinguish between relationship-preserving and end-game norms. ${ }^{12}$ For example, Macaulay's study found that although buyers and sellers entered into contracts that entitled the seller to recover expectation damages (an EGN) if the buyer failed to take the quantity of goods ordered, buyers "expected to be able to cancel orders freely subject to only an obligation to pay for the seller's

(1993) (averaging the weights provided by each of the parties to calculate damages when neither party complied with either the contract provisions or the trade rules relating to weights); CPC Int'l Trading Corp. v. I.S. Joseph Co., NGFA Case No. 1571 (1982) ("[B]oth parties erred and the guilt must be shared equally."); Feeders Grain Co. v. Italgrani U.S.A. Inc., NGFA Case No. 1575 (1982) ("[Because] both parties were negligent in checking each other's contracts ... [,] half of Plaintiff's claim [should] be allowed . . . . ); Farmers Grain v. Louis Dreyfus Corp., NGFA Case No. 1562 (1981) (splitting the amount of the discount because "it was apparent that neither party .. . reported grades as prescribed in the Grain Trade Rules"); Tabor \& Co. v. Cargill Inc., NGFA Case No. 1520 (rendering a compromise judgment, the arbitrators explained that the amount allowed was an arbitrary determination reflecting in part the market conditions at the time, in part the fact of a willful contract violation on the part of the Defendant, and in part dilatory and imprecise behavior of the part of the Plaintiff"), modified on appeal, NGFA Arb. App. Case No. 1520 (1976) (reducing the judgment to $\$ 12,500$ because the defendant's improper actions were not "willful"). On one occasion, the arbitrators split the difference because there was not a clear remedy in the trade rules. See R.F. Cunningham \& Co. v. F.M. Brown's Sons Inc., NGFA Case No. 1622 (1985) (holding that because "there is not a clear-cut remedy in the Trade Rules, it is the arbitration panel's opinion that the two parties split the claim").

${ }^{109}$ See Interviews with Eight Grain Dealers (June 1995).

${ }^{110}$ See Interview with Texas Feed Dealer (Mar. 1995); Interviews with Three Texas Feed Dealers (Jan. 1996).

III The consequences of opportunism associated with this departure from the contract's terms are not severe. If a transactor thinks his trading partner has shortchanged him in filling a particular shipment, he can reweigh the shipment on his scales and, if he finds a discrepancy, he can insist that official weights be obtained for all future transactions.

${ }^{112}$ See Macaulay, Preliminary Study, supra note 82, at 61-62. 
major expenses, ${ }^{113}$ a norm closely approximating reliance damages. Sellers confirmed that in settling such disputes in situations where lawyers had not yet become involved, they routinely accepted these reliance-type payments in complete satisfaction of their claims. Reliance damages seem to be the transactors' preferred RPN. ${ }^{114}$

The study also found that businessmen "will negotiate a solution when a problem arises apparently as if there had never been any original contract, ${ }^{1115}$ with the dominant attitude being that "[y]ou can settle any dispute if you keep the lawyers and accountants out of it."116 This suggests that transactors negotiate primarily, though not exclusively, in the shadow of RPNs when their relationship is not at an end-game. As one businessman explained, "if something comes up you get the other man on the telephone and deal with the problem. You don't read legalistic contract clauses at each other if you ever want to do business again. ${ }^{n 17}$ In those infrequent instances where "relatively contractual methods are used to make adjustments in ongoing transactions and to settle disputes," this is usually done because the "[d]emands of one side ... are deemed unreasonable by the other ... [in which case they] occasionally are blocked by reference to the terms of the agreement between the parties."118 This suggests that when one transactor observes the other transactor deviating from implicit RPNs, he may respond by invoking or threatening to invoke an EGN. In sum, Macaulay's study suggests that the terms of a written contract are

$113 \mathrm{Id}$. at 61 .

114 Another study also found the payment of reliance damages to be the preferred RPN even though contracts entitling the breached-against party to expectation damages were often used. See Note, The Statute of Frauds and the Business Community: A Re-appraisal in Light of Prevailing Practices, 66 YALE L.J. 1038, 1061 \& n.64 (1957) (reporting the results of a survey of manufacturers' practices which found that when customers canceled orders, " $30 \%$ [of the manufacturers] always or usually take no action at all, $61 \%$ settle for expenses incurred, and $9 \%$ insist upon a settlement of expenses plus lost profits"). It is not surprising that reliance damages would be a more prevalent RPN than expectation damages. Reliance damages are easier than expectation damages to estimate objectively, so they are better suited to contexts where damages are calculated without the assistance of a third-party neutral and extensive discovery is unavailable. However, it is important to note that in many contracting contexts, if damages are quickly and voluntarily tendered, the difference between the expectation and reliance measures is likely to be small.

${ }^{115}$ Macaulay, Preliminary Study, supra note 82, at 61 .

116 Id.

${ }^{117} \mathrm{Id}$.

${ }^{118}$ Id. at 62. 
viewed as relevant primarily when transactors have decided not to deal again, that is, when their relationship is at an end-game.

The legislative history of the Code provides more explicit evidence that merchants do not necessarily want RPNs to be applied by courts in end-game situations. In an early draft of the Code, Llewellyn proposed replacing the perfect tender rule with a rule of substantial performance that made a price adjustment, rather than rejection, the consequence of nonconforming tender. Llewellyn defended his proposal on the ground that it reflected the ways that merchants generally dealt with nonconforming tender and would "impose the better practice of the marketplace as a rule of law." The New York Merchants Association, however, took the position that "the price adjustments that merchants made when goods 'are not entirely up to standard'- 'the give and take of ordinary mercantile life,' should not be made obligatory in the law." ${ }^{120}$ It lobbied for retaining the perfect tender rule, explaining that while the rule did create a risk that buyers would opportunistically reject goods in a falling market, this type of opportunism could "take care of [itself] 'mighty quick' through [other] merchant practices," such as sellers demanding cash in advance from buyers with a reputation for this sort of behavior. ${ }^{121}$ The Association further explained that a rule of substantial performance would not only create a risk that sellers would opportunistically "unload all their shopworn and defective goods, ${ }^{n 22}$ but would also give juries a vast amount of discretion that would lead to erratic and error-prone decisions. In the merchants' view, the combination of the perfect tender rule and nonlegal sanctions was more advantageous than a rule of substantial performance with judicial discretion. ${ }^{123}$

119 Zipporah B. Wiseman, The Limits of Vision: Karl Llewellyn and the Merchant Rules, 100 HARV. L. REV. 465, 525 (1987).

${ }^{120} I d$. at 526.

121 Id.

122 Id. (quoting National CONFERENCE OF COMM'RS ON UNIFORM STATE LAWS, CONSIDERATION IN COMMITTEE OF THE WHOLE OF THE FIRST TENTATIVE DRAFT OF THE AMENDMENTS TO THE UNIFORM SALES ACT 65 (1940)).

${ }^{123}$ See id. For further evidence that transactors do not necessarily want all of their legally unenforceable obligations to be legally enforceable, see Note, supra note 114, at 1060 ("The reluctance of the manufacturers as a group to extend the present scope of legal protection afforded [oral] business agreements is especially significant, since most of the manufacturers who indicated that they do not favor such an extension obtain promises from their customers or suppliers that are not enforceable under existing law."). 
Thus, merchants recognize the distinction between relationshippreserving and end-game norms, and do not necessarily want RPNs to be used to resolve end-game disputes. However, courts applying the Code's usage of trade, course of dealing, and course of performance provisions routinely take RPNs into account in deciding cases where the transactors' relationship is at an end-game stage. ${ }^{124}$ This adjudicative approach may impose an efficiency loss on transactors not only because it prevents them from selecting their preferred mix of legal and extralegal provisions, but also because in many contexts the content of RPNs is likely to be different from the content of efficient EGNs. ${ }^{125}$ In order to more fully understand the ways that the Code's adjudicative approach affects contractual relationships, even in situations where disputes requiring third-party adjudication never arise, it is useful to separately consider the effects of courts looking to RPNs reflected in trade usages and the effects of courts looking to RPNs created by transactors' courses of performance and courses of dealing.

${ }^{124}$ It is, however, important to note that not every contracting relationship that results in a dispute requiring third-party adjudication is at an end-game stage. Sometimes transactors are simply unable to reach agreement and may find it desirable to turn the dispute over to their lawyers and get on with business. However, even in such situations, it might not be desirable for courts to use RPNs to resolve disputes. First, because RPNs often condition on information that is observable but unverifiable, courts applying such norms will often be making errorprone inquiries that transactors do not view as cost-justified. See supra notes 91-97 and accompanying text. Second, in cases where courts look to RPNs reflected in transactors' courses of performance, the inquiry required by the Code will force transactors to scrutinize their past interactions. The party arguing that past actions do not constitute a course of performance will typically attempt to characterize the parties' past dealings as contentious, in an effort to show that the disputed actions were not "acquiesced in without objection." U.C.C. $\$ 2-208(1)$. As a consequence, the Code may make it difficult for transactors to maintain their commercial relationship once a dispute requiring adjudication has arisen. In contrast, NGFA's arbitration system and its adjudicative approach are designed to enable companies to submit disputes to arbitration while minimizing the disruption to their relationship. For example, the Association strongly discourages oral hearings because they tend to increase the amount of emotional energy that parties invest in the dispute and lead to a more substantial deterioration of the relationship than arbitrations conducted without an oral hearing. See NGFA, PROTECTING, supra note 17, at 127 (reporting the opinion of the general counsel to a large grain company "that the customary NGFA arbitration which is conducted entirely through written presentation supported by documents ... is less destructive to personal and corporate relationships than utilizing the right under the Arbitration Rules for oral hearings"); Interview with NGFA National Secretary (June 1995) (same).

${ }^{125}$ See supra notes 105-06 and accompanying text. 


\section{A. Usage of Trade}

The Code includes usages of trade in the terms of merchants' legally enforceable agreements and looks to them to "give particular meaning to the language used ${ }^{n 126}$ in written contracts. It justifies doing so on the theory that because a majority of transactors implicitly contract with reference to usages, ${ }^{127}$ requiring transactors to memorialize the usages they want to be legally enforced in written provisions would be prohibitively expensive. ${ }^{128}$ However, even in markets where transactions are concluded using detailed, standard-form memoranda or trade-association-drafted standardform contracts, so that the cost per transaction of memorializing usages in boilerplate is likely to be low, unwritten usages often diverge from express contractual provisions. This suggests that the emergence and endurance of certain practices as usages, rather than as common contractual provisions, may be due to considerations other than drafting costs.

Some practices may remain unwritten usages for reasons of historical accident, or because deeply embedded social practices discourage greater formalization. ${ }^{129}$ Others may remain usages for many of the same reasons that individual transactors sometimes find it advantageous to allocate aspects of their contracting relationship to the extralegal realm. Practices may, for example, remain unwritten usages because they condition on observable but unverifiable information, or because the legal system costs associated with including them as legally enforceable provisions would be prohibitively high. Finally, many practices may remain usages because they reflect the RPNs that transactors in the market as a

\footnotetext{
${ }^{126}$ U.C.C. \$ 1-204 cmt. 4.

127 See id. \$ 2-202 cmt. 2 ("[W]ritings are to be read on the assumption that ... usages of trade were taken for granted when the document was phrased.").

${ }_{123}$ See SCHWARTZ \& SCOTT, supra note 5, at 64-65 (noting and questioning the idea behind the Code's trade usage provision, namely "that the cost of negotiating individual sales contracts is reduced [when courts look to trade usage] since parties can use 'off the rack' assumptions of trade usage without specifically enumerating them ... [s]ince they are common practices, most bargainers would choose them

${ }^{129}$ In the diamond industry, for example, the endurance of a transactional paradigm that makes diamond contracts difficult, if not impossible, to enforce in court is due, in part, to the large number of orthodox Jews in the diamond industry and the religious prohibition on one Jew suing another in civil court. See Bernstein, Diamonds, supra note 86, at 141 (citing THE PRINCIPLES OF JEWISH LAw 20-21 (Menachem Elon ed., 1974)).
} anyway"). 
whole are willing to abide by when they trust the person they are dealing with or want to preserve their relationship. ${ }^{130}$

Courts that look to unwritten trade practices in resolving endgame disputes may therefore impose an efficiency loss on transactors. By enforcing obligations that were rationally allocated to the extralegal realm, they will be making inquiries that transactors agreed ex ante were not worth the cost, and by enforcing RPNs they will often be imposing costly obligations that transactors would not have agreed to assume absent the prospect of a continuing contractual relationship.

It might be argued that even if usages do reflect RPNs or the terms of extralegal agreements rather than transactors' desired EGNs, the Code's trade usage provision need not impose any efficiency loss because transactors can contract around usages they do not want incorporated into their contract. However, even if transactors can satisfy the Code's strict requirements for contracting around a usage, ${ }^{131}$ doing so will only protect them from legal enforcement of the usage in situations where they do not want to follow the usage. In situations where transactors want to follow a usage, but do not want their obligation to do so to be legally enforceable, contracting around the usage may not offer complete protection from legal enforcement. If transactors routinely abide by the usage, there is a significant risk that a court will incorporate it into their agreement as either a course of dealing or a course of performance, thereby making any expense incurred in negating the usage a deadweight loss. In practice, the Code makes it very difficult for transactors to enter into a legally unenforceable agreement to follow an established trade usage. It may therefore discourage transactors from behaving, and promising to behave, in ways that would likely increase the value of their contracting relationship.

The legal system costs associated with the Code's trade usage provision may also be significant. It is relatively easy to state a claim where the existence and/or content of a usage is disputed, so that the claim survives a motion for summary judgment. ${ }^{132}$ This

${ }^{130}$ Usages of trade may not, however, reflect the most efficient RPN for a particular set of transactors or transactors in the market as a whole. See Posner, supra note 106 (exploring a variety of reasons why even the norms of relatively close-knit groups will not necessarily be efficient).

${ }^{151}$ See supra notes 73-74 and accompanying text.

192 See, e.g., C-Thru Container Corp. v. Midland Mfg. Co., 533 N.W.2d 542, 545 (Iowa 1995) (denying the defendant's motion for summary judgment on the ground 
may increase transactors' incentives to file nuisance suits. In addition, when courts look to unwritten usages to decide cases, the risk that their interpretation of the content of the usage will differ from the transactors' interpretation is likely to be greater than it is when the court is interpreting an explicit contractual provision. This uncertainty over the rule that a court would apply may increase the likelihood both that transactors will have a dispute and that, if a dispute arises, they will have divergent views about the expected trial outcome. This may, in turn, increase the likelihood of a bargaining impasse, particularly if each transactor is overly optimistic that a court would determine the content of the usage in a manner favorable to her. The more overly optimistic each transactor is, the more likely it is that a settlement range will not exist and that a settlement will not be reached. ${ }^{133}$

Finally, although the Code's adjudicative philosophy presupposes the existence of an embedded set of unwritten customs that are truly known and agreed to by transactors, there is some evidence that the existence of such customs might be less pervasive than the Code assumes. The codification of customary norms in written trade rules by numerous trade associations that provide commercial arbitration conducted by industry-expert adjudicators $^{134}$ suggests that merchants may believe that without codifica-

that there was a disputed issue of material fact as to the existence of a trade usage that the plaintiff sought to introduce to supplement the terms of a fully integrated writing).

${ }^{133}$ See Robert Cooter et al., Bargaining in the Shadow of the Law: A Testable Model of Strategic Behavior, 11 J. LEGAL STUD. 225, 225 (1982) ("The usual approach to bargaining in the legal setting assumes that trial is caused by excessive optimism on the part of the plaintiff and defendant."); Daniel Kahneman \& Amos Tversky, Conflict Resolution: A Cognitive Perspective, in BARRIERS TO CONFLICT RESOLUTION (Kenneth J. Arrow et al. eds., 1995) (discussing the psychological tendency for the parties engaged in a dispute to overestimate their chances of success).

${ }_{134}$ For example, the following associations have codified their customs into trade rules: American Cotton Shippers Association, American Fats and Oils Association, American Peanut Shellers Association, American Seed Trade Association, American Spice Trade Association, American Tin Trade Association, Association of Food Industries, Binding Industries of America, Burlap and Jute Association, Cocoa Merchants' Association of America, Colorado Grain and Feed Association, Diamond Dealers Club, General Arbitration Council of the Textile and Apparel Industries (Worth Street Rules), Green Coffee Association of New Orleans, Green Coffee Association of New York, Kansas City Board of Trade, Memphis Cotton Exchange, Merchants Exchange of Portland, Mid-America Commodity Exchange, National Cottonseed Products Association, National Hay Association, National Institute of Oilseed Products, North American Wholesale Lumber Association, Pacific Coast Coffee Association, Pacific Northwest Grain and Feed Association, Pennsylvania Rice Millers' Association, Rubber Trade Association, Specialty Coffee Association of 
tion custom would be too vague and uncertain to be either a satisfactory guide to proper commercial behavior or a sufficiently certain basis for arbitrator decisionmaking. ${ }^{135}$ One of the primary reasons NGFA decided to codify its customs was that customs differed so much from one locale to another that codification was necessary to reduce the incidence of misunderstandings and to facilitate the growth of a national market. ${ }^{136}$

\section{Caveat}

When a generalist court resolves disputes between merchants, its interpretive decisions are likely to come closer to the transactors' expectations if it looks to trade usage to "give particular meaning .... to [contract] terms." ${ }^{137}$ However, this type of interpretive accuracy comes at a cost. There is no consistent way to distinguish between usages that explain the trade meaning of express contractual provisions and those that supplement or qualify the meaning of such provisions. Any rule to be applied by a generalist court, other than a specific gap-filling rule, ${ }^{138}$ must therefore either entirely exclude evidence of trade usage or permit it to be introduced for all of the purposes identified in the Code. In contracting contexts where the cost of contract-

America, Tea Association of the USA, Texas Cotton Association, and the Texas Grain and Feed Association. See Lisa Bernstein, The Newest Law Merchant: Private Commercial Law in the United States, at tbl. 1 (Nov. 26, 1995) (unpublished manuscript, on file with author). Many other associations publish codes of industry standards or promulgate standard-form contracts that memorialize industry custom in contractual boilerplate. See id.

${ }^{135}$ There are, however, other explanations for these industries' decisions to codify their customs. First, codifying custom reduces arbitrators' discretion (because they do not have to determine the content of the rule), which may make arbitrator bias easier to detect and hence less likely to occur. Second, codifying custom reduces the cost of dealing with someone in a location with different unwritten customs. Finally, the codification of customs is particularly beneficial to large companies that operate in many areas, because they would otherwise have to appoint a large number of local agents familiar with local norms or would have to educate their employees about different local customs.

${ }^{136}$ In addition, interviews with six small Texas feed dealers established that trade practices and the meanings that transactors attach to common contractual provisions differ significantly in different parts of Texas. See Interviews with Texas Feed Dealers (Jan. 1996).

${ }^{137}$ U.C.C. $\$ 1-205 \mathrm{cmt} .4$.

${ }^{138}$ When the Code's specific gap-filling provisions that direct courts to look to commercial practice when the contract is silent are strictly applied, they will not have the same undesirable effects as the Code's general trade usage provision so long as they are applied only when the contract is truly silent. 
ing under the Code's trade usage provision is significant, there may be less costly ways for transactors to obtain the benefits of more trade-specific interpretive decisions. For example, in transactions where standard-form contracts are used, transactors could include usages in boilerplate provisions. Alternatively, in transactions where transactors cannot reduce the "true meaning" of their agreement to a writing with sufficient specificity at a reasonable cost, but want their relationship to be governed by customary norms, they could designate an industry-expert wiseman to resolve disputes in accordance with industry norms. ${ }^{139}$ Given the cost and delay involved in litigation, and the need for courts to determine the content of such norms from the often conflicting testimony of expert witnesses, such approaches may be costeffective.

In short, recognizing the undesirable effects of the Code's trade usage provision on commercial relationships suggests that while looking to usages may improve the accuracy of judicial decisions, and may be desirable in certain contexts, some merchant-transactors may nonetheless prefer either to forgo the benefits of this type of trade-specific interpretive accuracy or to obtain it in other, less costly, ways.

\section{B. Course of Dealing and Course of Performance}

Courses of dealing ${ }^{140}$ or courses of performance may also reflect RPNs, ${ }^{141}$ because they are typically established by introducing patterns of behavior transactors have engaged in over time

${ }^{139}$ The use of a nonjudicial third-party as a contract administrator in long-term relationships was also suggested by Robert Scott. See Robert E. Scott, Conflict and Cooperation in Long-Term Contracts, 75 CAL. L. REV. 2005, 2049 (1987) ("A more sensible means of exploiting the considerable power of the long-term relationship may be appointment of a permanent contract referee ... [,] a single arbiter who can minimize both information and enforcement problems on an ongoing basis.").

${ }^{140}$ For simplicity of exposition, this Section will focus primarily on course of performance. However, it is important to note that: (1) course of dealing is somewhat easier to contract out of than course of performance because, unlike some courses of performance, its content is known by transactors at the time of contracting; and (2) because the longer transactors have been dealing with one another, the more likely they are to trust one another and be willing to act in ways that differ significantly from the terms of their contract, RPNs reflected in courses of dealing may diverge more markedly from the EGNs in transactors' written contracts than the RPNs reflected in transactors' courses of performance.

${ }^{141}$ But see infra part III.B.5 (suggesting that in some contexts course of performance might reflect a pattern of hold-up under a contract). 
without objection. When transactors anticipate that courts will use RPNs reflected in their courses of performance or courses of dealing to resolve end-game disputes, they will be less likely to flexibly adjust their contractual obligations. They may also find it more difficult to create stable frameworks for renegotiation and to maintain long-term commercial cooperation.

\section{Flexibility}

When transactors are deciding whether to take an action that might later be deemed a course of dealing or course of performance, their decision about whether or not to take the action will affect, even if it does not completely determine, the likelihood that if a dispute arises, a court will look to the action taken to interpret the meaning of the transactors' written agreement and/or to determine whether they had implicitly agreed to a modification or waiver of its terms. The fact that a court might look to the action taken to determine the meaning of a contract will, in most instances, either decrease or leave unchanged the likelihood that the transactors will decide to take the action.

There are certain types of adjustments a transactor might be willing to make at many discrete points in an ongoing contractual relationship that she would nonetheless be unwilling to promise to make. Consider, for example, a contract for the sale of ten sacks of flour per month for twelve months for ten dollars per sack, payable on the first of the month. Suppose that the buyer $(B)$ asks the seller $(S)$ if he can pay fifteen days late in January. If $S$ 's cash-flow position is good, and $B$ is a valued customer, $S$ may agree to accept late payment. If the same situation arises in each of several subsequent months, and $S$ 's cash flow remains good, she may continue to accept late payment. However, even though $S$ was willing to accept late payment on several occasions, and may, in fact, be willing to accept late payment on future occasions, if $S$ cannot accurately predict her own cash-flow situation, she may nonetheless be unwilling to promise to accept late payment whenever it is requested by $B .{ }^{142}$

$142 S$ may also be unwilling to agree to a provision obligating her to accept late payment whenever her cash flow is good. A court may be unable to verify whether her cash flow is good, and the legal system costs of including a provision conditioning on such a vaguely defined consideration may be significant. A suit on the clause initiated by $B$ would be likely to get past summary judgment, because there would undoubtedly be disputed issues of material fact. As a consequence, inclusion of the 
In such a situation, although there are sound business reasons that $S$ would be willing to accept late payment on many occasions but would be unwilling to promise to accept late payment, a court presented with evidence that $S$ had accepted late payment on several occasions would likely find the acceptance of late payment to be a course of performance. It might therefore be construed as an enforceable part of the transactors' agreement, a modification of the payment clause, a waiver of the payment clause, or an important interpretive consideration. If $S$ anticipates that her acceptance of late payment without objection on a few occasions may be construed by a court as having created a contractual obligation to continue to accept late payment, she might refuse to accept late payment on more than one occasion. ${ }^{143}$ Thus, the Code's course of performance provision reduces the likelihood that transactors in ongoing relationships will flexibly adjust their contractual obligations, even in situations where it would be desirable for them to do so.

The effect of the Code's course of performance provision on transactors' willingness to flexibly adjust their obligations will depend, in part, on whether the course of performance reflects the transactors' decision to follow the terms of an extralegal agreement reached at the time of contracting, or instead reflects either their decision to follow the terms of an extralegal agreement reached after the contract was signed or a series of spot adjustments. When the desired course of performance is in accord with an extralegal agreement reached at the time of contracting, transactors may be able to adjust the terms of their written contract to reduce the likelihood that a court will view a particular course of performance as creating or modifying a legally enforceable obligation.

Consider, for example, a transaction for the sale of 100 bushels of No. 2 hard winter wheat a month for ten months at one dollar per bushel. Suppose that the transactors want to enter into an

clause would increase the risk that $B$ would file a nuisance suit with significant settlement value, thereby reducing the value of the transaction to $S$. See David Rosenberg \& Steven Shavell, A Model in Which Suits Are Brought for Their Nuisance Value, 5 INT'L REV. L. \& ECON. 3, 3 (1985) (presenting a model that illustrates how a plaintiff who is able to credibly threaten to inflict high litigation response costs on a defendant before having to incur significant costs himself may be able to extract a settlement "even though the defendant knows the plaintiff's case is sufficiently weak that he would be unwilling or unlikely actually to pursue his case to trial").

${ }^{143}$ See U.C.C. $\$ 2-208 \mathrm{cmt}$. 4 (providing that "[a] single occasion of conduct does not fall within the language of this section"). 
extralegal agreement to negotiate a price adjustment when the wheat is slightly off-grade, but do not want the adjustments they make under this agreement to be construed by a court as establishing a course of performance that makes a price adjustment, rather than rejection of nonconforming tender, the legally enforceable norm. ${ }^{144}$ In such a situation, the transactors could reduce the likelihood that a court would find a series of price adjustments to be a legally enforceable course of performance by including a provision in their contract stating that "in the event that $S$ delivers wheat that grades below No. 2, $B$ has the right to reject the goods unless an agreement to adjust the price is reached." If such a provision were included in the contract and a dispute relating to a delivery of off-grade wheat arose after several consensual adjustments had been made, $B$ would then be able to argue that in making the previous adjustments he was simply exercising one of his options under the contract. A court might therefore be less likely to impose a price adjustment as a contractual obligation arising from a course of performance and might give $B$ the right to reject the off-grade goods.

Thus, the effects of courts taking course of performance into account when the course of performance reflects adherence to the terms of an extralegal agreement reached at the time of contracting can, to some extent, be avoided by altering the way the contract is drafted. Transactors may also be able to make these sorts of drafting adjustments when they anticipate that a court will look to course of dealing or usage of trade to define their obligations, because these considerations are also known at the time of contracting. However, this method of contracting around the Code's interpretative approach will be ineffective in situations where transactors cannot anticipate the type of flexibility they wish to preserve, or where drafting and negotiating a provision to cover each situation in which flexibility might be desirable would be either impossible or prohibitively expensive.

Once a contract has been entered into and transactors are considering an action that either conflicts with the terms of their contract or relates to something the contract does not cover, the Code effectively gives them three options. First, transactors can take the action while explicitly disclaiming its prospective applicabil-

14 See supra notes $120-23$ and accompanying text (discussing the New York Merchants Association's testimony on the desirability of the Code's proposed rule of substantial performance). 
ity. This may damage their relationship and may not completely eliminate the action's effect on the court's interpretation of their agreement. Second, they can decide not to take the action, thereby losing whatever benefits the adjustment would have created. Third, they can take the action and bear the expected costs associated with the action's effect on the way a court would interpret their contract. Regardless of the option they select, however, the transactors are worse off than they would be in a NGFA-type system. The Code creates barriers, not only to transactors choosing the value-maximizing combination of legally enforceable contractual provisions and extralegal provisions, but also to their flexibly adjusting aspects of their contracting relationship in ways that might increase the value of their contracting relationship.

\section{Renegotiation}

In contexts where transactors anticipate that they will often have to renegotiate particular aspects of their agreement, they may select the written contractual provisions that will set the most desirable parameters for renegotiation. ${ }^{145}$ These provisions may differ from the provisions that particular transactors, or transactors in the market as a whole, typically agree to when successful renegotiation takes place. In such contexts, if transactors anticipate that courts will permit course of performance to alter the meaning of their written contract, it may be difficult for them to draft provisions that will set a desirable and stable framework for renegotiation. As their contracting relationship develops and repeated adjustments are made, the fact that in the event that renegotiation fails, courts will look to course of performance in defining and interpreting the terms of the contract or deciding whether a waiver or modification

145 Although the reasons that particular contract provisions are selected cannot be established with certainty, there is evidence from a study comparing covenants in the contracts governing bank loans, privately-placed debt, and publicly-traded debt suggesting that many of the covenants in the contracts that govern privately-placed debt are used because they set a desirable framework for renegotiation, not because either the borrower or lender expects them to be strictly enforced. See MARK CAREY ET AL., THE ECONOMICS OF THE PRIVATE PLACEMENT MARKET, BOARD OF GOVERNORS OF THE FEDERAL RESERVE SYSTEM 5 (1993) (providing evidence that in the privateplacement market "borrowers choosing contracts with restrictive covenants also tend to be served by lenders that provide flexible renegotiation of the contracts," while similarly "tight covenants are not present in widely distributed debt because diffuse owners cannot efficiently... renegotiate," and concluding that the expected ease and frequency of renegotiation strongly influence the types of provisions commonly found in different types of debt contracts). 
of its terms has been made means that each transactor's threat point in the renegotiation, the point which defines the position that she will be in if renegotiation is unsuccessful, will constantly change, making nearly any framework for renegotiation established at the time of contracting inherently unstable.

\section{Cooperation}

The Code's effects on flexibility and renegotiation may also make it more difficult for transactors to maintain cooperative contracting relationships, particularly in repeat-dealing contexts or long-term relational contracts. In these situations, contractual obligations are often less precisely defined. As a consequence, transactors will sometimes inadvertently behave in ways that appear opportunistic or will mistakenly classify the other transactors' actions as opportunistic. Under such conditions, cooperation is more likely to be maintained when both transactors follow a norm of not responding to every action that appears opportunistic with a suit for breach of contract or termination of a mutually beneficial extralegal agreement. ${ }^{146}$ Transactors may, for example, adopt a policy of attempting to negotiate adjustments in response to such actions until either a particularly harmful breach occurs or a pattern of smaller breaches leads one transactor to conclude that he is better off terminating the relationship because he is dealing with an untrustworthy transactor who will continue to behave opportunistically.

The Code's course of performance provision, however, increases the cost of agreeing to forgiving adjustments. It creates a significant risk that a series of such adjustments will be found to constitute a course of performance that will operate as a waiver or modification of the contract's EGNs and will limit the circumstances in which they can be invoked. Thus, by discouraging the emergence of transactional norms that include the most desirable combinations of forgiving adjustments and threats to invoke EGNs in appropriate circumstances, the Code may reduce the likelihood that long-term cooperative relationships will arise and endure.

145 See Avinash K. Dixit \& BarRy J. Nalebuff, Thinking Strategically: The COMPETITIVE EDGE IN BUSINESS, POLITICS, AND EVERYDAY LIFE 114 (1991) (exploring the ways that relatively forgiving strategies can promote cooperation in a variety of situations). 


\section{Caveat}

In theory the Code offers transactors a way to minimize, though not eliminate, the impact of actions and adjustments on their subsequent obligations by noting their "objection" at the time the adjustment is made or the action is taken. ${ }^{147}$ In practice, however, it is difficult for transactors to completely and reliably negate the influence of actions and adjustments on the interpretive process. $^{148}$ In addition, even if transactors could adequately negate the effect of these adjustments by simply noting their objections for the record, they might nevertheless be reluctant to make their objections known, because doing so might damage the contracting relationship or send a negative signal about their desirability as exchange partners. ${ }^{149}$

\section{Other Distortions}

In assessing the desirability of the Code's course of performance provision, it is important to note that there is a reason, apart from mutually beneficial adjustments, that a course of performance may deviate from the terms of a contract, or may seem to supply terms in face of a contractual gap, particularly in a long-term relationalcontract setting where the written contract is largely incomplete. Courses of performance sometimes reflect patterns of hold-up under a contract. A transactor may ask for an adjustment at one

${ }^{147}$ See U.C.C. § 2-208(1) ("Where the contract for sale involves repeated occasions for performance by either party with knowledge of the nature of the performance and opportunity for objection to it by the other, any course of performance accepted or acquiesced in without objection shall be relevant to determine the meaning of the agreement.").

${ }^{148}$ In thinking about the desirability of default rules from a practical point of view, it is also important to consider the stages in a contracting relationship where a lawyer is typically present. Lawyers are more likely to be present when contracts are drafted than they are at each stage of performance when the objection necessary to avoid an action being construed as a modification or waiver must be made. As a consequence, the Code may encourage lawyers, whose personal interests may lead them to be even more concerned about the event of breach than are their clients, to advise clients to note their objection to everything that deviates from the explicit obligations outlined in the contract. If this advice is written into company policies, it will decrease flexibility and may undermine cooperation.

${ }^{149}$ The Article 2 Revision Committee recently endorsed moving the Code's course of performance provision to Article 1, where it would apply to all aspects of commercial relationships governed by the Uniform Commercial Code. However, the analysis presented here suggests that such an amendment would have undesirable effects on commercial relationships and should therefore be opposed. 
point in time, and the other transactor may consent, reasoning that the request was due to unforeseen circumstances and that the prospective value of the relationship is so high that it is worthwhile to agree. This may happen a few times, until the transactor agreeing to the concessions realizes that each request is not a plea for cooperation in changed circumstances, but rather a part of a pattern of attempts to extract concessions. After realizing this, the transactor who had been agreeing to concessions will reevaluate the prospective value of the relationship under the assumption that the requests for concessions will continue, and may conclude that there is no longer any reason to preserve the relationship. He may therefore decide to declare breach and bring suit on the contract. A court looking at this behavior may find the terms of the contract to have been supplemented, modified, or waived by the course of performance. It may therefore enforce the extortionist's terms. Although a court would not do so if these terms appeared unreasonable, a transactor may still gain significant financial advantage by following this course of action, because courts may not be able to adequately distinguish small hold-ups from flexible adjustments of the relationship. ${ }^{150}$

\section{Expansion of Commercial Practices}

Finally, it is important to note that to the extent that courses of performance or courses of dealing that are not required by the terms of transactors' written contracts, but that are widely observed by numerous transactors over time, give rise to new trade usages, ${ }^{151}$ the fact that the Code systematically discourages such courses of action from being followed by making transactors less willing to deviate from the terms of their written contracts and less

${ }^{150}$ It is important to note that a move to a legal regime that did not enforce courses of performance would affect transactors' reliance decisions. When transactors are aware that course of performance will not be taken into account, however, they can adjust their reliance decisions to reflect their view of the strength of the nonlegal sanctions supporting the extralegal agreement and can structure their relationship (by, for example, dividing performance that deviates from the contract's explicit terms into smaller increments, thus reducing vulnerability) to increase the effectiveness of these sanctions. Alternatively, in situations where they would make particularly large reliance decisions were their relationship to be governed by the current Code regime, they could still enter into legally enforceable modifications that would enable them to obtain the benefits of legal enforcement.

${ }^{151}$ See JOHN GRAY, HAYEK ON LIBERTY 34-40 (2d ed. 1986) (discussing Hayek's theory of spontaneous order). 
willing to enter into extralegal agreements means that its adjudicative approach will inhibit the "continued expansion of commercial practices through custom, usage and agreement of the parties." 152 In addition, to the extent that the Code also tends to discourage transactors from including contractual provisions varying existing usages, because existing usages are likely to remain relevant to interpretation of the provision that attempts to alter them, ${ }^{133}$ the Code will also retard the expansion of commercial practices through innovative contractual drafting. ${ }^{154}$ This tendency is reinforced by the discount that the Code's contextualized approach imposes on the benefit of drafting innovative express terms by making it less likely that they will be enforced as written.

\section{THE IMPORTANCE OF TRANSACTIONAL AND INSTITUTIONAL CONTEXT}

The analysis presented here has identified a variety of reasons that sophisticated merchant-transactors may prefer an adjudicative approach that is largely acontextual and gives primacy to the express terms of written agreements. This Part explores certain aspects of grain and feed transactions and the institutional environment created by NGFA that make a formalistic adjudicative approach particularly well-suited to the private adjudication of disputes among grain and feed merchants.

152 U.C.C. § 1-102(b). For example, the Code's adjudicative approach decreases the likelihood that usages that condition on observable but unverifiable information, particularly those that involve actions that are taken more than once in a typical contracting relationship, will arise. Consider two transactors who are considering following the practices required by a nascent usage that conditions on unverifiable information but has not yet become widely enough followed to constitute a usage under the Code. In such a situation, the transactors would reason that if they followed the usage on more than one occasion and a dispute arose, a court would take it into account as a course of performance. However, because the usage conditions on unverifiable information, this is something the transactors would find undesirable. As a consequence, they would be reluctant to follow the usage in the first place. Because most transactors would reason in a similar manner, the Code reduces the likelihood that practices that condition on unverifiable information will become usages. It is, however, possible that some such usages may continue to arise in transactional settings where transactors view the probability of a dispute going to court as being exceptionally low, and the benefit of following the usage as being exceptionally high.

${ }^{153}$ See supra notes 73-74 (discussing the difficulty of completely negating a usage). 151 Cf. Goetz \& Scott, supra note 90, at 276-79 (reaching the same conclusion). 


\section{A. Transactional Context}

One of the main reasons that a formalistic approach is wellsuited to NGFA's adjudication of disputes is that the types of events that can disrupt a grain or feed transaction are, except in highly unusual circumstances, known by transactors at the time of contracting. Most of these contingencies are dealt with through either a trade rule or an explicit provision in a standard-form memorandum, making the typical contract for the purchase of grain or feed close to the ideal-type complete contingent state contract. Unlike many types of contracting relationships governed by the Code, in which the written contract does not completely define the relationship between the transactors, grain and feed contracts are well-specified..$^{155}$ In addition, because most contracts are negotiated quickly on the telephone, transactors tend not to include complex nonstandard provisions. ${ }^{156}$ As a consequence, NGFA arbitrators are confronted with fewer gaps and interpretive disputes than courts.

A primary shortcoming attributed to NGFA-type adjudication is that judgments may not be well-tailored to the facts of particular

155 There are a number of other aspects of the institutional environment created by NGFA that encourage the drafting of complete contracts. First, given NGFA's adjudicatory philosophy, the value of including an express provision is greater than it is in a contract governed by the Code, because the provision is more likely to be enforced as written. Second, because relative to litigation, the NGFA system reduces the cost and increases the accuracy of third-party fact-finding and dispute resolution, more information will be verifiable, that is, worthwhile to prove to the NGFA arbitrators, than would be verifiable in litigation. As a consequence, contracts that will be interpreted and enforced in the NGFA system can be more complete than contracts that will be interpreted and enforced in court, because they can include provisions conditioning on a broader range of considerations. Third, NGFA's widely circulated opinions routinely chastise transactors whom arbitrators view as having left unwarranted gaps or ambiguities in their agreement, thereby giving transactors an incentive not to leave gaps. See, e.g., Fred Webb Inc. v. Cargill Inc., NGFA Case No. 1691 (1993) ("This dispute would have been avoided if the parties had addressed the type of destination grades to be used."); Dixie Portland Flour Mills Inc. v. Guthrie Cotton Oil Co., NGFA Case No. 1637 (1988) ("The arbitration panel wished to emphasize that the contract terms themselves may be a partial cause of this dispute. It is the obligation of both buyer and seller to make certain the contract terms accurately reflect their intentions . . . ."); Leo Hinson v. Parker Grain Co., NGFA Case No. 1628 (1986) ("The arbitration panel was unanimous in wishing to caution the trade as to the necessity of using well-thought-out contracts that clearly encompass all of the obligations of both buyers and seller to each other."); Gulf Coast Grain Co. v. Central States Enters., NGFA Case No. 1569 (1982) ("[C]ompanies must recognize the risks they are taking if delivery terms are not specific.").

${ }^{156}$ See Interview with Grain Company Lawyer (Jan. 1995). 
cases. However, grain and feed transactions are so standardized that the facts of any particular case are likely to be close to the archetypal transaction contemplated by the drafters of the trade rules. In addition, because the amount at stake in a typical dispute tends to be small, ${ }^{157}$ due in part to the existence of a well-developed spot market that makes cover and mitigation readily available and a trade rule that provides that "[f]ailure to perform in keeping with the terms and conditions of a contract shall be grounds for the refusal only of such shipment or shipments and not for the rescission of the entire contract or any other contract between Buyer and Seller, ${ }^{n 158}$ the consequences of adjudicative error in any one case will often be small relative to the assets of the parties. Therefore, transactors in the market as a whole may view any inefficiencies introduced through lack of tailoring in a particular case as being vastly outweighed by the cost savings and other benefits created by NGFA's adjudicative approach.

Finally, NGFA's adjudicative approach creates important benefits for large grain companies, who employ hundreds of contracting agents (merchandisers) who enter into numerous contracts each day as well as hundreds of shipping clerks who fill hundreds of contracts a day. Because NGFA refuses to imply terms that do not appear in written contracts or the trade rules, employees cannot unobservably bind their companies to obligations not contained in their companies' standard-form contracts. If an employee wants to execute a binding rider to the contract, the rider must be signed and in writing. By relieving large companies of the need to implement controls that would prevent their agents from unobservably binding them to obligations, NGFA's adjudicative approach may reduce large companies' intrafirm agency costs. ${ }^{159}$ Furthermore, the codification of custom and the lack of enforcement of unwritten usage mean that merchandisers for large companies will not have to incur the substantial cost of learning dozens of local customs. NGFA's adjudicative approach therefore substantially reduces the cost to large companies of dealing in geographically dispersed markets.

${ }^{157}$ Between 1975 and 1990, NGFA's largest award was $\$ 138,040$. See Triple " $F "$ Feeds v. Cook Indus., NGFA Arrb. Case No. 1532 (1977).

${ }^{158}$ NGFA GRAIN TRADE R. 43.

${ }^{159}$ In general, companies are likely to favor trade rules and adjudicative approaches that minimize the sum of intrafirm agency costs and the transaction costs of dealing with other firms. 


\section{B. Institutional Context}

Unlike the Code, which was designed to govern many different types of transactions and therefore includes many vague gap-filling provisions that are tailored to the particular case by looking to commercial context, the NGFA Trade Rules are narrowly tailored to the industry's needs. They precisely define the meaning of common contractual language, ${ }^{160}$ embody many of the industry's established customs and usages, and provide a menu of preformulated terms that transactors can easily reference in their contracts. As a consequence, the marginal benefit of NGFA arbitrators looking to unwritten usage in an effort to tailor the meaning of a contractual provision or trade rule is far less than the marginal benefit of a court looking to these considerations to tailor a vague Code default rule or interpret an ambiguous contractual provision. Because the trade rules are well-suited to most transactions, transactors draft fewer nonstandard clauses than they would if the Code were to govern their contracts. ${ }^{161}$ When transactors do include nonstandard clauses, such clauses tend to be drafted clearly. The prospect that such clauses will be routinely enforced as written gives the drafter an added incentive to draft the terms clearly, because their full value will be realized if a dispute arises.

Although NGFA arbitration is formalistic, settlements negotiated in its shadow may nevertheless reflect equitable considerations. NGFA arbitrators sometimes rule in favor of a party on the basis of an explicit contractual provision or trade rule, while at the same time noting in their widely circulated opinions that although the winning party "technically prevailed," he nonetheless acted contrary to an unwritten usage, good business practices, the spirit of a trade rule, or an implicit understanding. ${ }^{162}$ As a consequence, transac-

${ }^{360}$ See, e.g., NGFA GRAIN TRADE R. 4 (defining, among other terms, "official weight," "affidavit Weight," and "official inspection"); NGFA GRAIN TRADE R. 8 (defining, among other terms, "shipment," "delivery," "prompt," and "first week"); NGFA GrAIN TRADE R. 13 (defining "buying-in" and "selling-out").

${ }^{161}$ See Goetz \& Scott, supra note 90, at 289 (discussing how the "state's provision of standardized contractual signals . . . create[s] a relative disadvantage to innovative instructions that depart from conventional terms").

${ }^{162}$ See, e.g., Louis Dreyfus Corp. v. Early \& Daniel Co., NGFA Case No. 1547 (1979) (holding for the defendant under the explicit terms of a trade rule, the arbitrators noted that " the arbitration committee sympathizes with the Plaintiff in his position," and feels "[ $t$ ]here is a question of fairness and intent which is raised in this case"). In addition, the arbitrators will sometimes criticize the business practices of both parties. See, e.g., General Mills Inc. v. Cook Indus., NGFA Case No. 1540 (1978) (ruling for the plaintiff but noting that "evidence clearly showed poor supervision of 
tors sometimes offer settlements even when they know they will prevail at arbitration. ${ }^{163}$ The arbitrators' willingness to send these types of signals may encourage transactors to reach settlements that reflect equitable considerations as well as the expected value of the arbitrators' monetary award. It may also encourage traders to settle disputes in situations where their individual egos are the primary barrier to settlement. In such situations, each trader may fear that being chastised for bad business practices in an arbitration opinion will limit his opportunities for advancement within his own company. ${ }^{164}$ When transactors are aware that an opinion will be written if an arbitration takes place, reputation bonds will be better able to ensure that transactors perform their obligations or settle their disputes in the shadow of their true understanding, thereby taking some of the harsh edge off the NGFA's bright-line, inflexible rules and its formalistic adjudicative approach. ${ }^{165}$

It is also important to note that NGFA's use of bright-line trade rules and a formalistic adjudicative philosophy severely restrict arbitrator discretion and minimize the need for arbitrators both to rely on and assess the credibility of testimony. This is particularly important in the trade-association context, where the adjudicators are themselves market transactors and the risk of adjudicative bias is perceived to be substantial. Combined with the requirement that NGFA opinions state the factual basis for their holdings, this

the trade and accompanying logistics [on the part of both companies]. Execution for the most part was handled by clerks and secretaries and not merchandisers and management. Both of these large companies should have been experienced in this area."); Cook Indus. v. Triple "F" Feeds, NGFA App. Case No. 1532 (1977) (affirming the primary arbitration panel's judgment against the defendant while noting that the "Arbitration Appeals Committee observes regretfully that both parties to this transaction left much to be desired in their preparation and performance of the contract").

${ }^{163}$ See Interview with Grain Dealer (Mar. 1996); Interview with Grain Company Executive (Mar. 1996); Interview with Grain Dealer (June 1995).

${ }^{16 t}$ See Interview with Grain Company Executive (June 1995) (explaining that in counseling individual traders to "work it out" with the other party, he often reminds them that it might hurt their prospects for advancement within the company to have their business practices criticized in an arbitration opinion); Interview with Three Grain Company Executives (May 1996) (noting that being chastised for bad business practices in an arbitration opinion can end a trader's career at a particular company).

${ }^{165}$ See Robert E. Scott, A Relational Theory of Default Rules for Commercial Contracts, $19 \mathrm{~J}$. LEGAL STUD. 597, 614-15 (1990) (suggesting, in an attempt to “explain the law's preference for clear, tough, winner-take-all default rules," that "[u]nderstood in their broader context [they] serve as an effective complement to the more flexible means of social adjustment," and "set the stage for cooperative adjustments that take place on an on-going, extralegal basis"). 
approach makes it easier for market participants to assess whether a given case was correctly decided. ${ }^{166}$ This, in turn, makes it easier for a tribunal to establish and maintain a reputation for impartiality and enables more nuanced information about transactors' reputation to be disseminated to the market.

Finally, because the institutional environment created by NGFA operates to strengthen extralegal enforcement mechanisms such as reputation bonds, ${ }^{167}$ extralegal agreements are likely to be valuecreating supplements to many grain and feed contracts, particularly among local or regional merchandisers who trade with one another on a repeat basis. As a consequence, ensuring that extralegal agreements remain extralegal is particularly valuable in grain and feed markets, making NGFA's adjudicative approach particularly well-suited to the private adjudication of grain and feed disputes.

\section{CONCLUSION}

This Article has identified a number of undesirable effects on commercial relationships between merchants created by the Code's search for immanent business norms. It has also suggested that the Code's highly contextualized approach to adjudication is flawed because it mistakenly assumes that transactors' actions under a contract are the best indication of what they intended their writing to mean, when in fact these actions are likely to reflect the RPNs transactors find it desirable to follow when they cooperatively resolve disputes, not the EGNs they would want a court to apply if they wind up in litigation. However, because the Code also governs other types of contracting relationships, such as merchant-toconsumer transactions, ${ }^{168}$ where the arguments in favor of contex-

${ }^{166}$ The publication of opinions appears to influence transactors' views of the integrity of the tribunal. See Interviews with Six Grain Dealers (June 1995). According to a Texas grain dealer who is a former chairman of the Texas Grain and Feed Association's ("TGFA") arbitration panel, the credibility of the TGFA arbitration system and the quality of the decisions it rendered improved dramatically when the association introduced a rule requiring the publication of opinions. See Interview with Texas Grain Dealer (June 1995).

${ }^{167}$ For example, NGFA: (1) circulates arbitration opinions to all members; (2) conducts trade-rules seminars and other educational programs that are designed, among other things, to create an industry-wide consensus about what constitutes acceptable commercial behavior; and (3) publishes a newsletter that prominently announces suspensions, expulsions, and noteworthy arbitration decisions.

168 The arguments in favor of allowing courts to look to course of dealing and course of performance to establish the terms and interpret the meaning of an agreement are far stronger in merchant-to-consumer transactions where the problems 
tualized adjudication may be stronger than they are in merchant-tomerchant transactions, the analysis presented here does not necessarily suggest that the entire Code should be amended to reflect a more formalistic adjudicative approach.

Rather, the arguments presented here, together with the empirical evidence from the NGFA arbitration system, suggest that the Code should be amended to include a "safe harbor" provision that would give merchant-transactors a simple and reliable way to either opt out of the Code's adjudicative approach or selectively opt out of its usage of trade, course of performance, or course of dealing provisions. Such a safe harbor would enable merchanttransactors to select their preferred degree of contextualized adjudication and would transform the Code's quasi-mandatory interpretive approach into a default approach that merchanttransactors could avoid when they found it advantageous to do so.

More generally, the analysis presented here suggests that the Article 2 Revision Committee should carefully rethink its sweeping endorsement of Llewellyn's adjudicative approach, an approach that was developed to be accommodating to merchant concerns but that has many undesirable effects on merchant transactions and undermines, rather than furthers, the Code's own stated goals of "preserv[ing] the flexible character of commercial contracts," and "permit[ting] the continued expansion of commercial practices through custom, usage and agreement of the parties." 170

of reliance and asymmetric information are often more pronounced. As between the terms of detailed contracts, the default rules of the Code, and their experience during the contracting relationship, consumers may often tend to rely on their personal experiences, which may make the Code's contextualized approach essential to protecting consumers.

${ }^{169}$ U.C.C. $\$ 2-208 \mathrm{cmt} .2$.

${ }^{170}$ Id. $\S 1-102(\mathrm{~b})$. 
